FINAL REPORT

FHWA/IN/JTRP-2004/9

\title{
NEW COMBINATION TREATMENTS FOR CONTROL OF JOHNSONGRASS ALONG ROADSIDES
}

\author{
By \\ D. James Morré \\ Professor \\ Department of Medicinal Chemistry and Molecular Pharmacology \\ Purdue University \\ Joint Highway Research Program \\ Project No. C-36-48P \\ File No. 9-5-15 \\ SPR-2398 \\ Prepared in Cooperation with the \\ Indiana Department of Transportation \\ and the \\ U.S. Department of Transportation \\ Federal Highway Administration
}

The contents of this report reflect the views of the authors who are responsible for the facts and the accuracy of the data presented herein. The contents do not necessarily reflect the official views or policies of the Federal Highway Administration and the Indiana Department of Transportation. This report does not constitute a standard specification or regulation.

Purdue University

West Lafayette, IN 47907

March 2005 


\section{TECHNICAL Summary}

INDOT Research

Technology Transfer and Project Implementation Information

TRB Subject Code: 40-7 Roadside Maintenance

Publication No.: FHWA/IN/JTRP-2004/9, SPR-2398

March 2005

Final Report

\section{New Combination Treatments for the Control of Johnsongrass along Roadsides}

\section{Introduction}

Considerations of cost savings, safety and appearance are among the major reasons for justification for seeking improved roadside maintenance practices. For Johnsongrass, there are several additional, even more compelling, reasons.

Johnsongrass is a noxious weed. The need for its control is dictated by law. Therefore, roadside Johnsongrass must be controlled. There are no alternatives.

An estimated 10,000 acres (4,000 ha) of Johnsongrass-infested roadsides are within the roadside maintenance programs of the Districts in the southern 1/3 to1/2 of the State of Indiana. Current costs of mowing and herbicide treatment are estimated to be between $\$ 300,000$ and $\$ 500,000$ annually.
Johnsongrass eradication (control) has traditionally been one of the most difficult weed control problems in both crop and non-crop situations. Some materials, effective on seedling Johnsongrass in cropland are of limited effectiveness on established Johnsongrass along roadsides. At present, Johnsongrass represents the last major roadside weed problem for which no satisfactory recommendation for control existed when this project was initiated.

The objectives of the research were to provide for eradication (control) of Johnsongrass along Indiana roadsides and to reduce current costs of maintenance by at least $\$ 100,000$ annually by reducing the need for mowing and by eliminating repeat applications of expensive, ineffective herbicides.

\section{Findings}

Combined target-directed laboratory and greenhouse studies identified a new candidate herbicide, Outrider which when combined with a new additive designated TR-IV gives eradication of Johnsongrass when applied to plants after less than 20 inches $(70 \mathrm{~cm})$ of growth or regrowth following mowing. The combination does not harm oversprayed established fescue or bluegrass. Based on limited implementation activities (two years experience), the recommendation is as a spot treatment.

A cold-adapted Johnsongrass ecotype has been identified in the Northern-most tier of counties in Indiana which provides a further threat of encroachment of roadside-established Johnsongrass onto adjacent cropland of considerable potential economic consequence.

\section{Implementation}

It is suggested that the recommendation of the SAC Committee to create a committed roadside Johnsongrass research area with controlled mowing and date of spraying be followed as a means of implementation. The recommended area was US-63 from Jct. I-74 south to Jct. 
US-36. A moderately low traffic highway and centrally located where Johnsongrass is abundant. The roadsides are fenced so that adjacent landowners are less likely to interfere. State and contractual activities would be carefully regulated and selected no mow and no spray areas would be posted. This is probably imperative if we are to achieve the goal of chemical control eradication of Johnsongrass along Indiana roadsides.

\section{Contacts}

For more information:

Prof. D. James Morre

Principal Investigator

Dept. of Medicinal Chemistry and

Mollecular Pharmacology

Purdue University

West Lafayette IN 47907

Phone: (765) 494-1388

Fax: (765) 496-3601

E-mail: morre@pharmacy.purdue.edu

\section{Indiana Department of Transportation}

Division of Research

1205 Montgomery Street

P.O. Box 2279

West Lafayette, IN 47906

Phone: (765) 463-1521

Fax: (765) 497-1665

\section{Purdue University}

Joint Transportation Research Program

School of Civil Engineering

West Lafayette, IN 47907-1284

Phone: (765) 494-9310

Fax: (765) 496-7996

E:mail: jtrp@ecn.purdue.edu

http://www.purdue.edu/jtrp 
TECHNICAL REPORT STANDARD TITLE PAGE

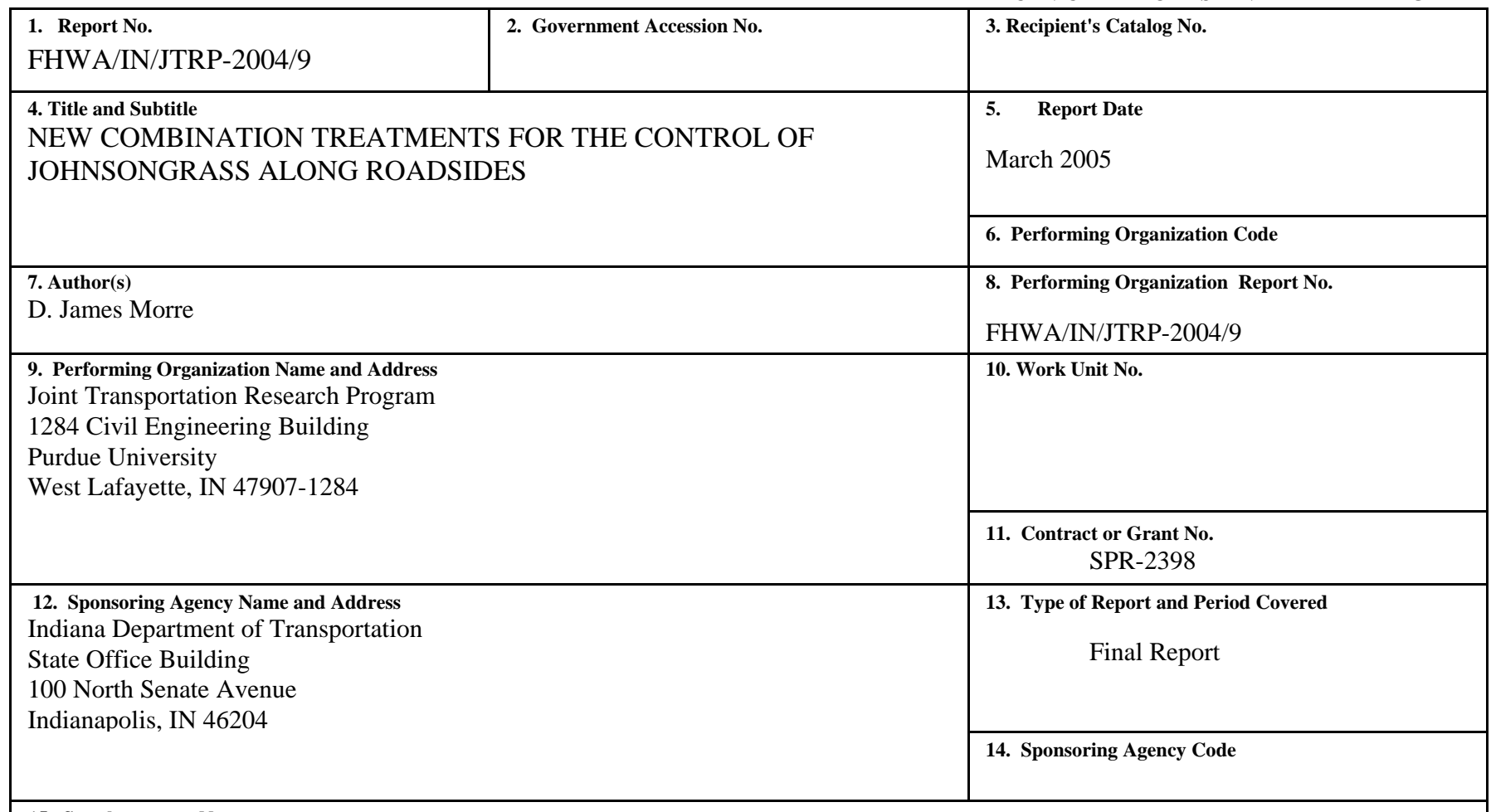

15. Supplementary Notes

Prepared in cooperation with the Indiana Department of Transportation and Federal Highway Administration.

\section{Abstract}

This project was to develop a cost-effective method for chemical eradication of Johnsongrass along Indiana roadsides. Johnsongrass, together with Canada thistle, represents Indiana's most serious noxious weed invader where the need for control is mandated by law. Combined target-directed laboratory and greenhouse studies identified a new candidate herbicide, Outrider, which when combined with a new additive designated TR-IV gives eradication of Johnsongrass when applied to plants after less than 20 inches $(70 \mathrm{~cm})$ of growth or regrowth following mowing. The combination does not harm oversprayed established fescue or bluegrass. Based on limited implementation activities (two years experience), the recommendation is as a spot treatment.

A cold-adapted Johnsongrass ecotype has been identified in the Northern-most tier of counties in Indiana which provides a further threat of encroachment of roadside-established Johnsongrass onto adjacent cropland of considerable potential economic consequence.

\begin{tabular}{|c|c|c|c|c|}
\hline \multicolumn{2}{|c|}{$\begin{array}{l}\text { 17. Key Words } \\
\text { Johnsongrass, chemical eradication, Outrider, noxious weeds }\end{array}$} & \multicolumn{3}{|c|}{$\begin{array}{l}\text { 18. Distribution Statement } \\
\text { No restrictions. This document is available to the public through the } \\
\text { National Technical Information Service, Springfield, VA } 22161\end{array}$} \\
\hline $\begin{array}{l}\text { 19. Security Classif. (of this report) } \\
\text { Unclassified }\end{array}$ & \multicolumn{2}{|c|}{$\begin{array}{l}\text { 20. Security Classif. (of this page) } \\
\text { Unclassified }\end{array}$} & $\begin{array}{r}\text { 21. No. of Pages } \\
46\end{array}$ & 22. Price \\
\hline
\end{tabular}




\section{TABLE OF CONTENTS}

Introduction (Problem Statement, Objectives and Work Plan) $\ldots \ldots \ldots \ldots \ldots \ldots \ldots \ldots$

Evaluation of Materials for Johnsongrass Existing at Start of Project $\ldots \ldots \ldots \ldots \ldots$

Laboratory, Greenhouse, and Field Studies to Identify a New Additive to Combine with Outrider. . 11

Roadside Small Plot Evaluations $2001-2003 \ldots \ldots \ldots \ldots \ldots \ldots \ldots \ldots \ldots \ldots \ldots$

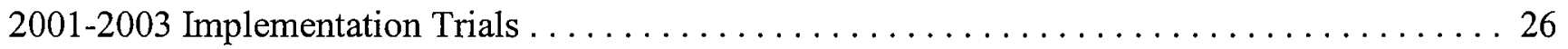

Northward Migration of Johnsongrass. Evaluation of a Cold-Hardy Ecotype. . . . . . . . . . 39

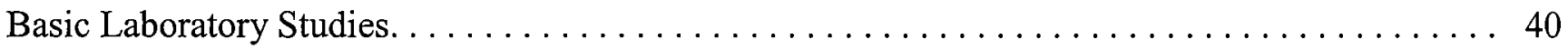

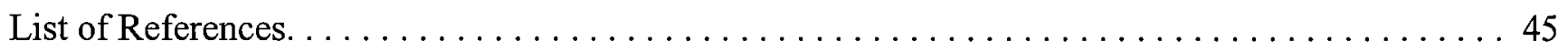

Conclusions $\ldots \ldots \ldots \ldots \ldots \ldots \ldots \ldots \ldots \ldots \ldots \ldots \ldots \ldots \ldots \ldots \ldots \ldots \ldots \ldots$

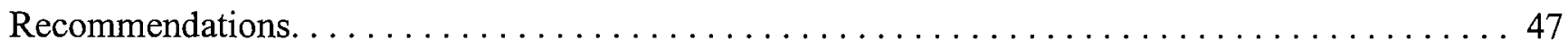

Implementation Suggestions $\ldots \ldots \ldots \ldots \ldots \ldots \ldots \ldots \ldots \ldots \ldots \ldots \ldots \ldots \ldots \ldots \ldots$ 


\section{TABLE OF FIGURES}

Figure 1. Response of NADH oxidation of 20 sections of dark-grown sorghum seedlings.... 7-10

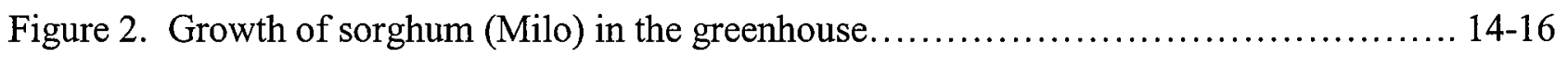

Figure 3. Response of field grown sorghum (Milo) to Outrider....................... 17

Figure 4. Response of field grown sorghum (Milo) to Outrider and Outrider plus GSSG.... 18

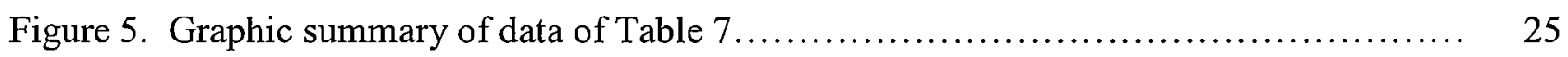

Figure 6. Johnsongrass Implementation Trial.................................... 28

Figure 7. Laboratory assays of NADH oxidase activity with plasma membranes............ 41

Figure 8. Laboratory assays of NADH oxidase activity............................. 42 


\section{TABLE OF TABLES}

Table 1. Roadside evaluation of Acclaim and Outrider alone and in combination.............. 4

Table 2. Roadside evaluation of Acclaim alone and in combination with Outrider............ 4

Table 3. Roadside evaluation of Outrider, Outrider plus borax, Acclaim and Acclaim plus

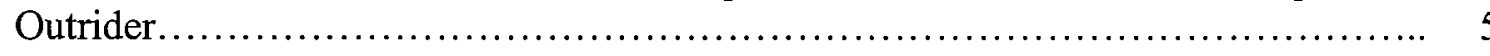

Table 4. Roadside evaluation of Outrider and Outrider plus borax. Crawfordsville District... 6

Table 5. Initial trial with Outrider plus additive TR-IV ............................... 6

Table 6. Growth of sorghum (Milo) in the greenhouse................................ 12

Table 7. Small plot Johnsongrass evaluations........................................ 21-24

Table 8. Fescue trial with Outrider and Outrider plus GSSG or GSH...................... 26

Table 9. Effect of several salt additives on Johnsongrass eradication...................... 44

Table 10. Effect of subsequent applications of Roundup............................. 


\section{1) IDENTIFICATION}

a) Title: NEW COMBINATION TREATMENTS FOR CONTROL OF JOHNSONGRASS ALONG ROADSIDES

b) Organization: Department of Medicinal Chemistry \& Molecular Pharmacology

Purdue University

West Lafayette, IN 47907

c) Principal Investigator: D. James Morré, Dow Distinguished Professor

d) Starting Date: August 1, 1999

\section{2) INTRODUCTION}

Considerations of cost savings, safety and appearance are among the major reasons for justification for seeking improved roadside maintenance practices. For Johnsongrass, there are several additional, even more compelling, reasons.

Johnsongrass is a noxious weed. The need for its control is dictated by law. Therefore, roadside Johnsongrass must be controlled. There are no alternatives.

An estimated 10,000 acres $(4,000 \mathrm{ha})$ of Johnsongrass-infested roadsides are within the roadside maintenance programs of the Districts in the southern $1 / 3$ to $1 / 2$ of the State of Indiana. Current costs of mowing and herbicide treatment are estimated to be between $\$ 300,000$ and $\$ 500,000$ annually.

Johnsongrass is an introduced perennial warm-season grass (6) that is robust [up to $6 \mathrm{ft}$ tall (2.5 $\mathrm{m})$ ] with dense foliage and limited in its habitat only by winter temperature (5-7). It is a superb competitor and usually overpowers other forms of roadside vegetation. It spreads both by rhizomes and by seed $(3,4)$.

While mowing or tillage will prevent reseeding and maintain sight distances and appearance, they do not result in reduced infestations or slow the spread from rhizomes. There are no known natural diseases, pests or possibilities for biological control. In order to reduce Johnsongrass infestations, herbicide treatments have been traditionally employed $(1,2)$.

In the preparation of a comprehensive program of roadside maintenance and recommendation (mowing and spraying) for Indiana roadsides, current herbicide treatments were evaluated and found to be only partially effective for Johnsongrass. Of the materials currently available and labeled for non-crop control of Johnsongrass is a material called Fusion (Zeneca Ag Chemicals). Fusion has been only partially effective in achieving Johnsongrass control with material applied at label rates. Even with repeated spraying, the Johnsongrass persists.

Chemicals effective on Johnsongrass, commercially produced, registered for non-crop applications and available for roadside use, are few at present. Horizon, one of the materials used successfully earlier in the program, is no longer available in a form labeled for non-crop 
use. It is also very expensive $(\$ 108 / 1)$. A few experimental materials are under development by Novartis and Monsanto but have not been systematically evaluated.

Johnsongrass eradication (control) has traditionally been one of the most difficult weed control problems in both crop and non-crop situations. Some materials, effective on seedling Johnsongrass in cropland are of limited effectiveness on established Johnsongrass along roadsides. At present, Johnsongrass represents the last major roadside weed problem for which no satisfactory recommendation for control exists.

Clearly, Johnsongrass control will require bold new approaches to treatment development. Past experience must be combined with new information and new lines of chemistry if we are to be successful in this project.

The objectives of the research were to provide for eradication (control) of Johnsongrass along Indiana roadsides and to reduce current costs of maintenance by at least $\$ 100,000$ annually by reducing the need for mowing and by eliminating repeat applications of expensive, ineffective herbicides.

The products of the research will include the following:

- A cost effective program of Johnsongrass eradication (control) using a combination with mowing (if necessary) and herbicide treatment.

- Cost savings in excess of $\$ 100,000$ annually.

- An evaluation of the environmental and applicator safety of the practices recommended.

- An implementation plan for moving the results into practice.

- Final report.

The research efforts during the study involved both laboratory (during winter months) and field (spring, summer and fall) studies. The project was divided into three phases with specific tasks to be accomplished in each phase.

Phase I. Selection of Materials

Phase II. Field Evaluations

Phase III. Implementation

\section{EVALUATION OF MATERIALS FOR JOHNSONGRASS CONTROL EXISTING AT START OF PROJECT}

At the time the project was initiated in August 1999, the best material for Johnsongrass control was Acclaim or Fusion (Horizon 2000). They were no longer offered in a form labeled for roadside use, were expensive and were not especially effective. Twice per year respraying was required at a cost of $\$ 30-50 / \mathrm{A}(\$ 75-125$ /ha) for materials. These materials were evaluated in several tests in late 1999 and early 2000.

The Horizon came from the soybean market under the name Acclaim and what we used was a Hoechst-Roussel product containing $12.5 \%$ fenoxaprop-ethyl:( \pm )-ethyl 2-[4-[(6-chlorobenzoxyazolyl))oxy]phenoxy]propanoate equivalent to $1 \mathrm{lb}$ of active material per gallon. 
The other material used with some success is called Fusion (Zepeca, Inc., Wilmington, DE). This is a mixture of fluazifop-P-butyl (24.15\%) and fenozaprop-P-ethyl $6.76 \%$ equivalent to ca. $2.5 \mathrm{lb} / \mathrm{g}$. This product is sold by Hoechst-Roussel as Horizon 2000 Herbicide (a mixture of Horizon and Fusilade 2000).

We applied $0.1 \mathrm{~kg} / \mathrm{ha}$ Fusion $+0.05 \mathrm{~kg} / \mathrm{ha}$ TR-III (cysteine) to which was added 1 $\mathrm{kg} /$ haammonium nitrate fertilizer. Early results this year suggest that the Fusion by itself at 0.2 $\mathrm{kg} / \mathrm{ha}$ gave $70 \%$ control and by itself at $0.1 \mathrm{~kg} / \mathrm{ha}$ gave $60 \%$ control. The combination gave $93 \%$ control. The problem was the neither product was labeled for roadside Johnsongrass.

A search of the existing literature revealed the use of borate (sodium metaborate) for nonselective vegetation control on non-cropped land and for spot treatment of Johnsongrass in cotton.

Four field trials were established in August 1999 on roadside Johnsongrass in the Crawfordsville and Seymour Districts. Also evaluated in early 2000 were Acclaim, Fusion and a new material, Outrider, not yet commercially available at that time but since made available (Tables 1-4). Outrider was tested alone at 0.5 and $1 \mathrm{oz} / \mathrm{A} \mathrm{(35}$ and $70 \mathrm{~g} / \mathrm{ha}$ ) together with TR-III additive at 0.05 $\mathrm{kg} / \mathrm{ha}$ and with $1 \mathrm{~kg} / \mathrm{ha}$ ammonium nitrate near Nashville, IN and in Austin, TX where the plants were unmowed and in late senescence and to mowed Johnsongrass 24 inches high at Purdue University adjacent to a greenhouse. Also compared was sodium metaborate as a single agent (no effect, not shown) and as an additive in combination with Outrider (Tables 3 and 4).

By July 4, 2000, the Bowling Green trial was mowed and oversprayed with Roundup. Johnsongrass in all treatments ceased growth, was yellowing and appeared stunted. The mixture of Acclaim and Horizon showed more yellowing than Acclaim alone. None of the treatments prevented regrowth the following season.

The most important observation of these studies was the observation that borax and Outrider were autogonistic (Table 4). This offered an opportunity for laboratory studies to utilize the borax observation to explore avenues toward eventual synergistic additive development. 
Table 1. Roadside evaluation of Acclaim and Outrider alone and in combination. Evansville, IN. Applied June 2, 2000. Rated July 3, 2000.

$\begin{array}{ll}0.25 & 85 \\ 0.5 & 85 \\ 1.0 & 90 \\ 1.5 & 90 \\ 2.0 & 90\end{array}$

Outrider, oz/A (g/ha)

$\begin{array}{ll}0.25+0.25(17) & 60 \\ 0.5+0.5(35) & 65 \\ 1.0+1.0(70) & 70 \\ 1.5+1.5(105) & 70 \\ 2.0+2.0(140) & 70\end{array}$

Acclaim, $\mathrm{kg} / \mathrm{ha}+$ Outrider, oz/A

\begin{tabular}{ll}
0.25 & 30 \\
0.5 & 40 \\
1.0 & 50 \\
1.5 & 50 \\
2.0 & 60 \\
\hline
\end{tabular}

Table 2. Roadside evaluation of Acclaim alone and in combination with Outrider. I-64 W, IN/IL State Line. Applied June 2, 2000. Rated July 6, 2000.

$\begin{array}{llc}0.25+0.25(17) & 90 \\ 0.5+0.5 & (35) & 100 \\ 1.0+1.0(70) & 100 \\ 1.5+1.5(105) & 100 \\ 2.0+2.0(140) & 100\end{array}$

Outrider, oz/A

$\begin{array}{lc}0.25 & 50 \\ 0.5 & 90 \\ 1.0 & 100 \\ 1.5 & 100 \\ 2.0 & 100\end{array}$

Table 3 Roadside evaluation of Outrider, Outrider plus borax, Acclaim and Acclaim plus 
Outrider. US50E, Brownstown. Applied June 16, 2000. Plants 3-5 ft. tall. Early anthesis.

Outrider, oz/A (g/ha)

$0.25(17)$

10

$0.5 \quad(35)$

30

$1.0 \quad(70)$

40

$1.5(105)$

0

$2.0(140)$

40

$4.0(280)$

40

Outrider, oz/A + Borax, kg/ha*

$0.25+10$

10

$0.5+20$

10

$1.0+40$

40

$1.5+60$

40

$2.0+80$

50

$2.5+100$

50

Acclaim, kg/ha

0.25

10

0.5

20

1.0

30

1.5

50

2.0

60

4.0

60

Acclaim, kg/ha + Outrider, oz/A (g/ha)
$0.25+0.25(17)$
5
$0.5+0.5$ (35)
25
$1.0+1.0(70)$
50
$1.5+1.5(105)$
60
$2.0+2.0(140)$
80

*20 Mule Team Borax, $0.5 \mathrm{lb} / \mathrm{gal}$ (60 g/l), $40 \mathrm{gpa}(300 \mathrm{l} / \mathrm{ha})$. Solubility of borax is about 2 $\mathrm{lb} /$ gallon $(240 \mathrm{~g} / \mathrm{l})$. Outrider is $75 \%$ sulfosulfuron. 
Table 4. Roadside evaluation of Outrider and Outrider plus borax. Crawfordsville District. Applied June 13, 2000. Plants 2-3 ft. tall (40-60 cm). Late anthesis. Rated June 21, 2000.

Outrider, oz/A (g/ha) Percent Control of Johnsongrass

$\begin{array}{lr}0.25(17) & 20 \\ 0.5(35) & 40 \\ 1.0(70) & 40 \\ 1.5(105) & 50 \\ 2.0(140) & 60\end{array}$

Borax, $\mathrm{kg} / \mathrm{ha}+$ Outrider, oz/A (g/ha)

$\begin{array}{lcl}10+0.25(17) & 30 \\ 20+0.5(35) & 20 \\ 40+1.0(70) & 20 \\ 60+1.5(105) & 50 \\ 80+2.0(140) & 60\end{array}$

Table 5. Initial trial with Outrider plus additive TR-IV. Applied to mowed Johnsongrass, 12 in $(40 \mathrm{~cm})$ high, US-231N, Crawfordsville.

\begin{tabular}{cccccc}
\hline Outrider $^{*}$ & GSSG & $2,4-\mathrm{D}$ & $\mathrm{X}-77$ & $7 / 9 / 01$ & $10 / 19 / 01$ \\
\hline & & & & & \\
$1 \mathrm{oz} / \mathrm{A}$ & - & - & $0.25 \%$ & 14 & 90 \\
$1 \mathrm{oz} / \mathrm{A}$ & $0.1 \mathrm{~kg} / \mathrm{ha}$ & $1 \mathrm{~kg} / \mathrm{ha}$ & $6.25 \%$ & 0 & 0 \\
$1 \mathrm{oz} / \mathrm{A}$ & $0.1 \mathrm{~kg} / \mathrm{ha}$ & $1 \mathrm{~kg} / \mathrm{ha}$ & $0.25 \%$ & 0 & 100 \\
$1 \mathrm{oz} / \mathrm{A}$ & - & - & $0.25 \%$ & 7 & 56 \\
- & $0.1 \mathrm{~kg} / \mathrm{ha}$ & - & $0.25 \%$ & 14 & 50 \\
- & - & - & $0.25 \%$ & 13 & 50 \\
\hline
\end{tabular}

$* 1 \mathrm{oz} / \mathrm{A}=70 \mathrm{~g} / \mathrm{ha}$

Figure 1. Response of NADH oxidation of 20 sections of dark-grown sorghum seedlings, $1 \mathrm{~cm}$ long, with and without the herbicide 2,4-D, to various potential additive salts (A-H), thiol compounds (L-M) and Outrider (J-M). Activities are steady state measured from the decrease in $\mathrm{A}_{340}$ over $120 \mathrm{~min}$. 


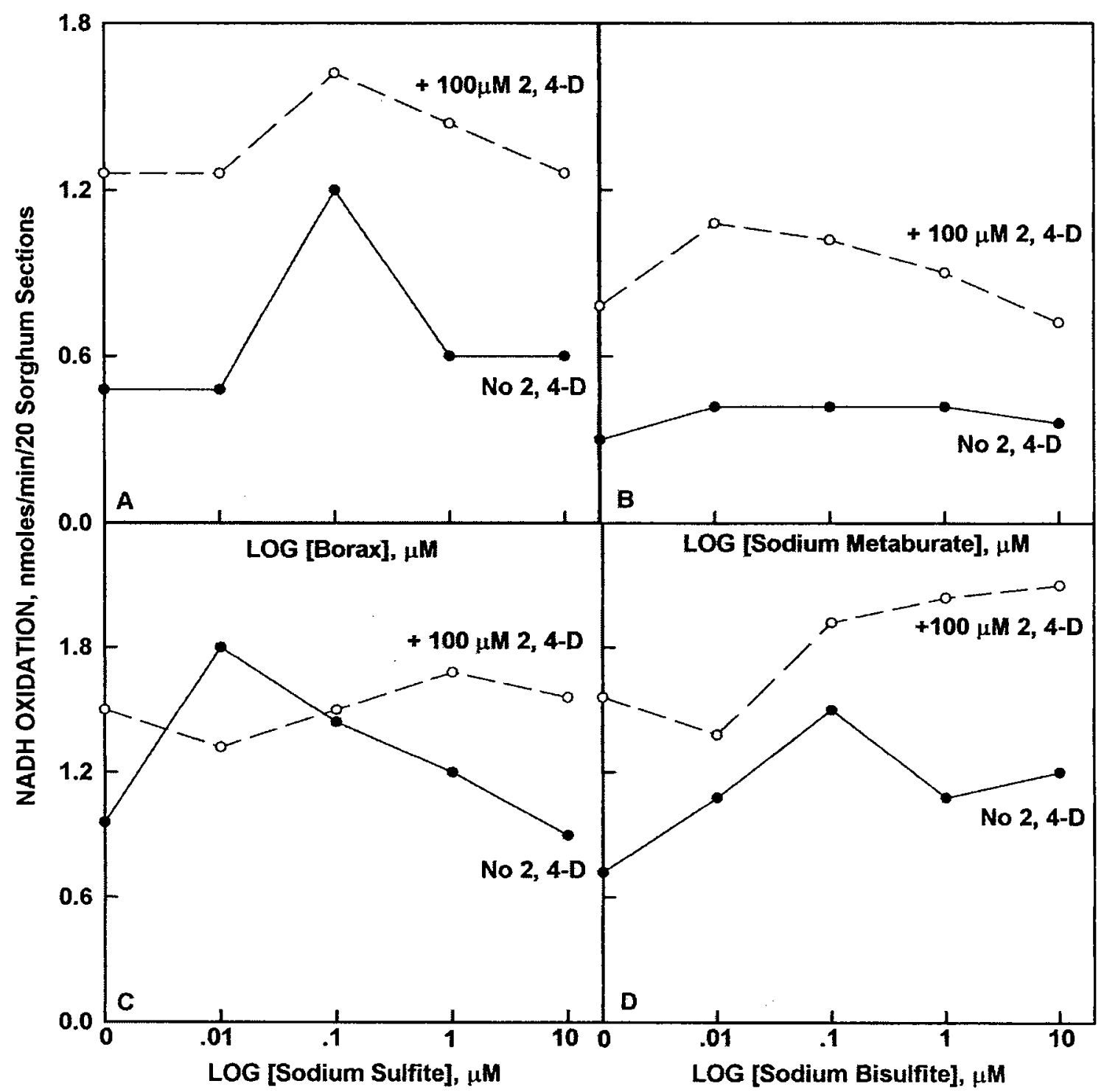

Figure 1. Response of NADH oxidation of 20 sections of dark-grown sorghum seedlings, $1 \mathrm{~cm}$ long, with and without the herbicide 2,4-D, to various potential additive salts $(\mathrm{A}-\mathrm{H})$, thiol compounds (L-M) and Outrider (J-M). Activities are steady state measured from the decrease in $\mathrm{A}_{340}$ over $120 \mathrm{~min}$. 


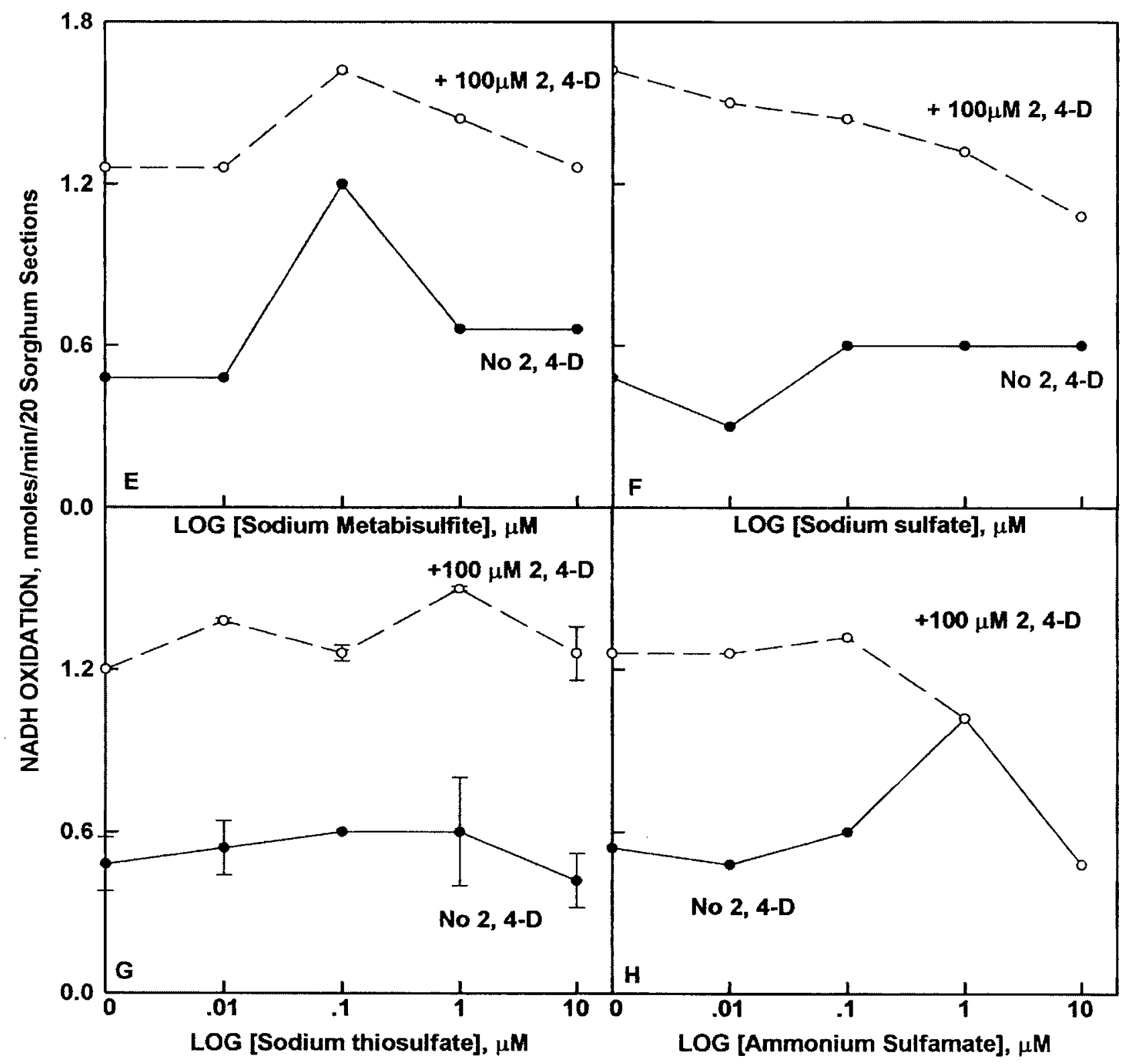




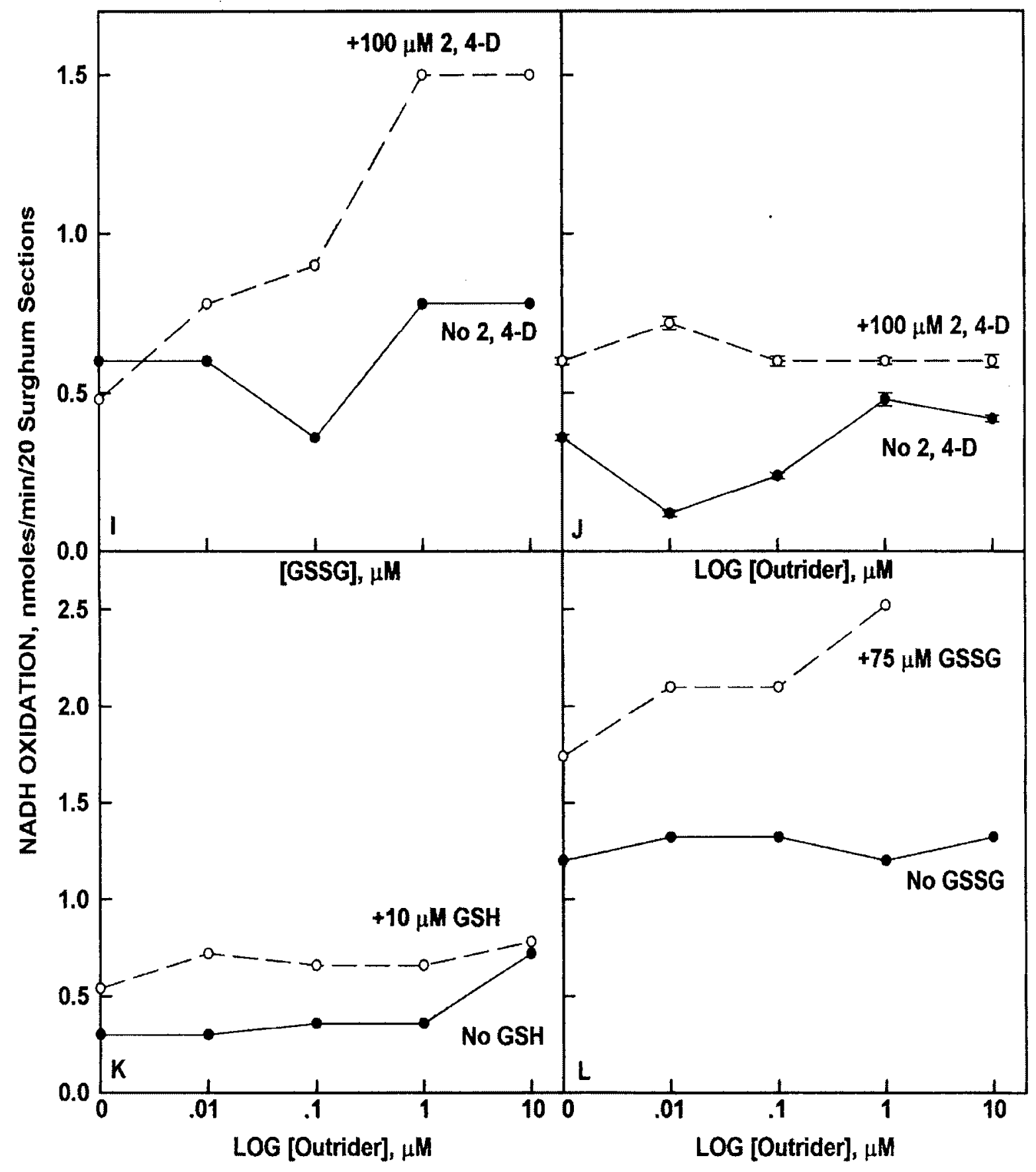




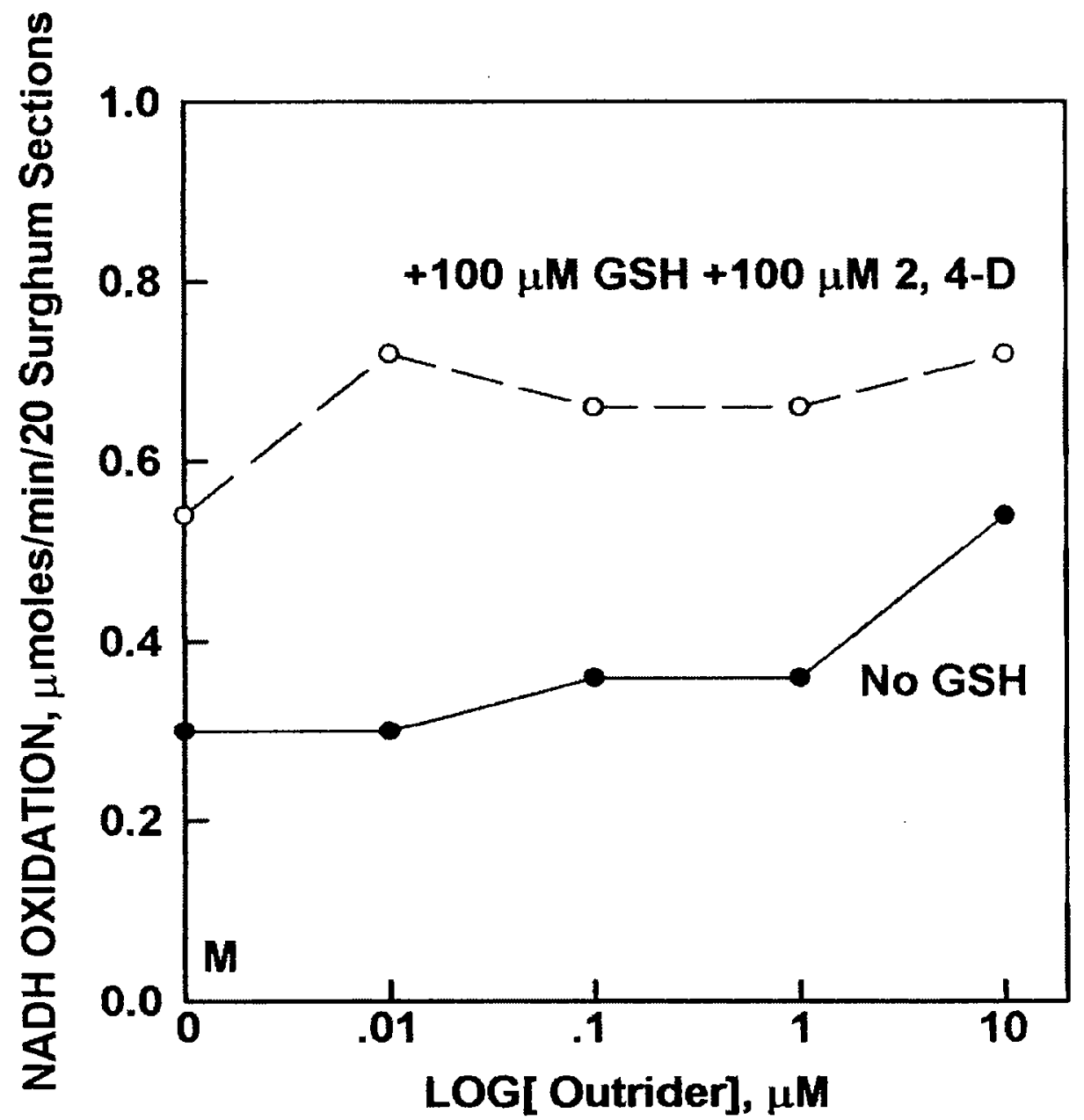




\section{LABORATORY, GREENHOUSE AND FIELD STUDIES TO IDENTIFY A NEW ADDITIVE TO COMBINE WITH OUTRIDER}

Based on the field studies of the previous section, an extensive series of studies were established using dark-grown seedlings of a commercial variety of Sorghum to evaluate Outride against a putative target protein and to seek low-cost means to provide for additive enhancement. The initial clue was antagonism of the activity of Outrider with borax where addition of borax to the Outrider resulted in reduced overall effectiveness of the Outrider. Antagonism usually signals an opportunity for synergy with related substances.

In the laboratory assay, both borax (Fig. 1A) and metaborate (Fig. 1B), were stimulatory. Also stimulatory were sodium sulfate (Fig. 1C), sodium bisulfate (Fig. 1D), sodium metabisulfate (Fig. 1E) and sodium thiosulfate (Fig. 1G) both in the presence or absence of the auxin herbicide 2,4-D. Inhibitions were observed with sodium sulfate (Fig. 1F), ammonium sulfamate (Fig. 1H), oxidized glutathione (GSSG) (Fig. 1I) and Outrider (Fig. 1J). Outrider and GSSG were most effective in the absence of 2,4-D. Reduced glutathione was without effect (Fig. 1K). A further observation was a dose-dependent interaction of GSSG with 2,4-D (Fig. 1I) that was retained in the presence of Outrider (Fig. 1L) but not observed with GSH (Fig. 1M).

The oxidized glutathione (GSSG) was designated Additive TR-IV and was then carried into field studies in August 2000 (Table 5).

Initial Small Plot Roadside Evaluations of Outrider with and without Additive TR-IV.

The first roadside evaluation of Outrider plus Additive TR-IV was in the fall of 2000 (August 18) on US $231 \mathrm{~N}$ in the Crawfordsville Subdistrict. Due to limited availability of experimental material, the experiment was unreplicated. Outrider at $1 \mathrm{oz} / \mathrm{A}(70 \mathrm{~g} / \mathrm{ha})$ applied to Johnsongrass 1 in $(40 \mathrm{~cm})$ tall reduced growth by about $50 \%$. The combination of $1 \mathrm{oz} / \mathrm{A}(70 \mathrm{~g} / \mathrm{ha})$ Outrider pluse $0.01 \mathrm{~kg} / \mathrm{ha}$ GSSG resulted in severe discoloration (deep red to black) of the Johnsongrass. Addition of 2,4-D was without effect and reduced glutathione (GSH) also was without effect. Evaluation of these plots the following spring confirmed that the Johnsongrass was eradicated by the treatment. Outrider $75 \mathrm{DF}$ alone was applied at 3 rates of 1,2 and $3 \mathrm{oz} / \mathrm{A}(70,140$ and 210 $\mathrm{g} / \mathrm{ha}$ ). In subsequent trials, Outrider alone was standardized at $1 \mathrm{oz}$ active material/A (70 g/ha). Two additional trials sprayed $9 / 9 / 200$ to 24 in $(80 \mathrm{~cm})$ Johnsongrass regrowth along US-231 N in Crawfordsville and to 24 in $(80 \mathrm{~cm})$ high Johnsongrass regrowth on September 11, 2000 at Purdue University (next to greenhouse) gave similar results to those of Table 5.

\section{Greenhouse Studies to Set the Ratio of Outrider to Additive TR-IV.}

Table 6 gives data of November, 2000, from the greenhouse where Outrider was combined with TR-IV at the rate of $0.1 \mathrm{~kg} / \mathrm{ha}$ in combination with Outrider at $1 \mathrm{oz} / \mathrm{A}(70 \mathrm{~g} / \mathrm{ha})$. The overall response to TR-IV in these experiments was antagonism suggesting that the ratio of TR-IV to Outrider was too high. Therefore, a series of experiments was next conducted to vary the TRIV/Outrider ratio (Fig. 2). 
Table 6. Growth of Sorghum (Milo) in the Greenhouse.

Control

Outrider, $1 \mathrm{oz} / \mathrm{A}^{*}$

Outrider, 1 oz/A + TR-IV (GSSG), 1 kg/ha

Outrider, $1 \mathrm{oz} / \mathrm{A}+$ TR-IV (GSSG), $0.1 \mathrm{~kg} / \mathrm{ha}$

Outrider, $1 \mathrm{oz} / \mathrm{A}+$ TR-IV (GSSG), $0.01 \mathrm{~kg} / \mathrm{ha}$

Outrider, 1 oz/A + TR-IV (GSSG), $0.001 \mathrm{~kg} / \mathrm{ha}$
$22 \pm 2$

$19 \pm 4$

$24 \pm 1$

$23 \pm 1$

$20 \pm 2$

$17 \pm 1$

${ }^{*} 70 \mathrm{~g} / \mathrm{ha}$

Sorghum growth was determined from 3 to 4 plants per $20 \mathrm{~cm}$ diameter pot per treatment. Results were based on four such experiments each from a different seed lot where synergy was observed between Outrider and TR-IV (GSSG) at $0.001 \mathrm{~kg} / \mathrm{ha}$. This rate of TR-IV would be economically feasible especially since it seemed to represent the difference between stunting and kill (Fig. 2). 
Sorghum Greenhouse II

Planted 11/22/00; Sprayed 12/27/00; Photographed 01/25/01
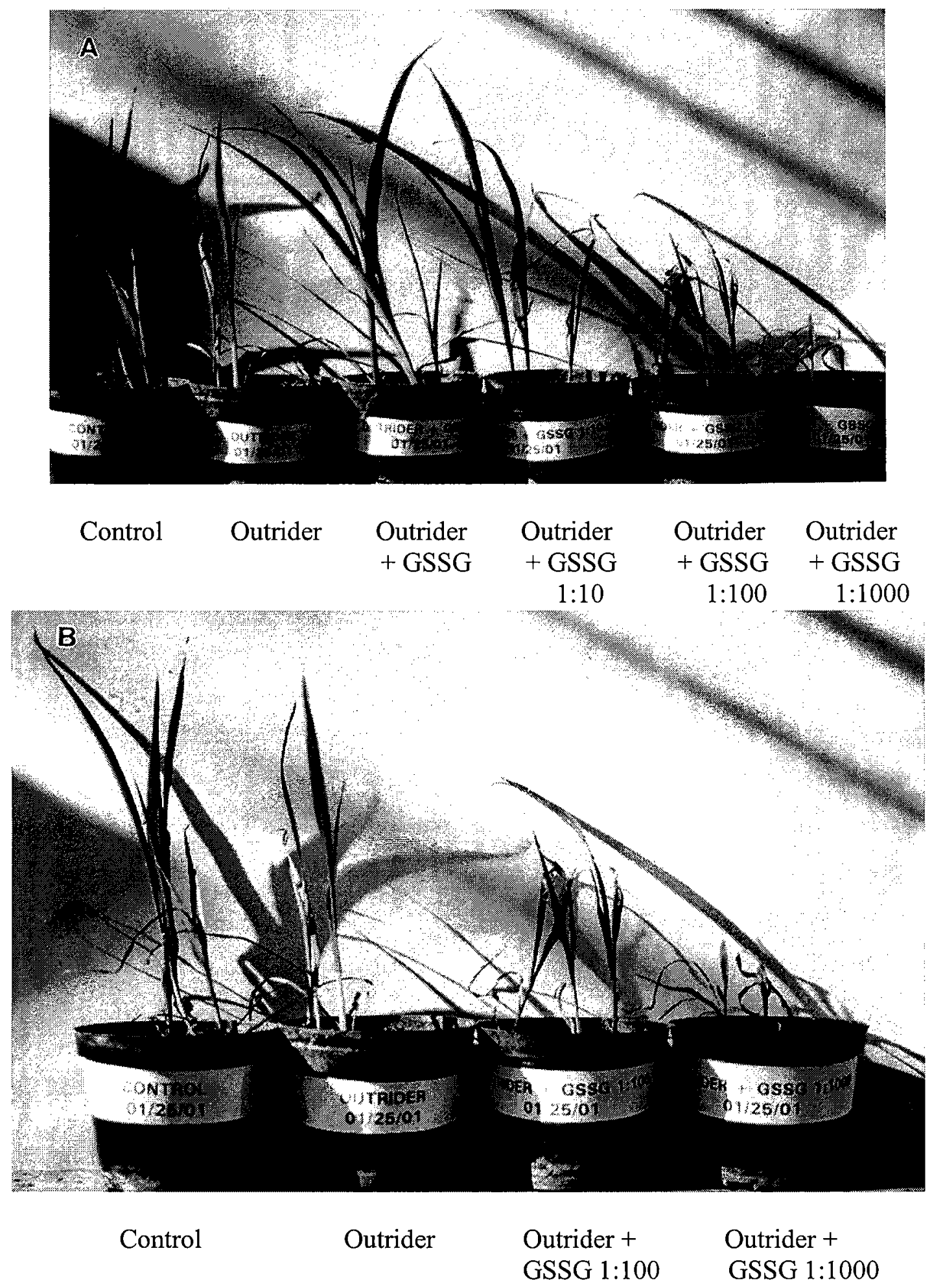

Figure 2. Growth of sorghum (Milo) in the greenhouse. The Outrider was constant at $1 \mathrm{oz} / \mathrm{A}(70 \mathrm{~g} / \mathrm{ha})$. The GSSG (TR-IV) rate at $1: 100 \mathrm{was} 0.001 \mathrm{~kg} / \mathrm{ha}=0.016 \mathrm{oz} / \mathrm{A}$. Data from sorghum Greenhouse I were similar (not shown). 
Sorghum Greenhouse III

Planted 12/19/00; Sprayed 01/19/01; Photographed 02/07/01

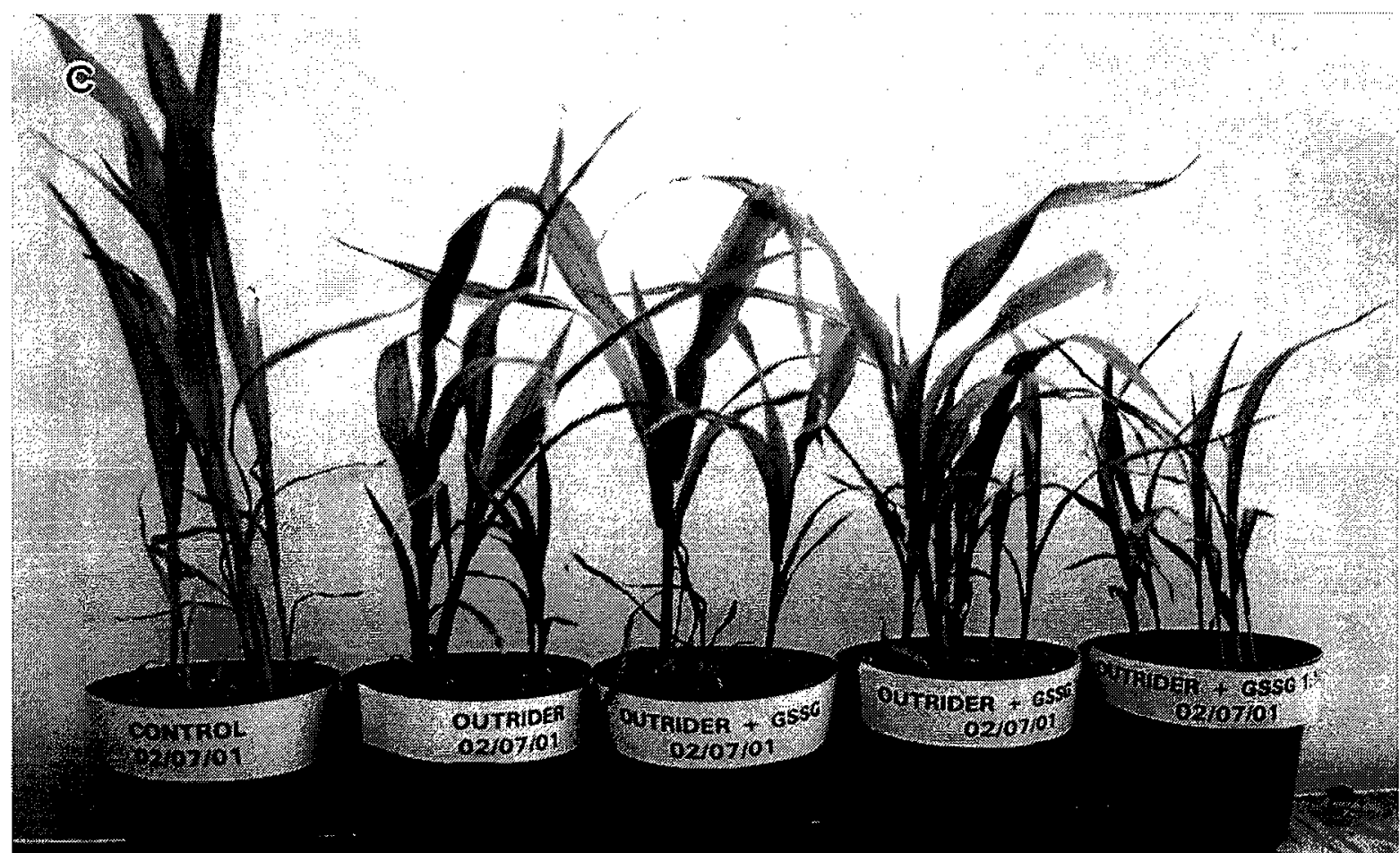

On 3/03/01 these plants were all dead. All other plants, including Outrider alone, were still alive and well but stunted in their growth. At least in this experiment, the addition of the GSSG was the difference between stunting and kill. 
Sorghum Greenhouse IV

Planted 01/19/01; Treated 02/09/01; Photographed 03/03/01

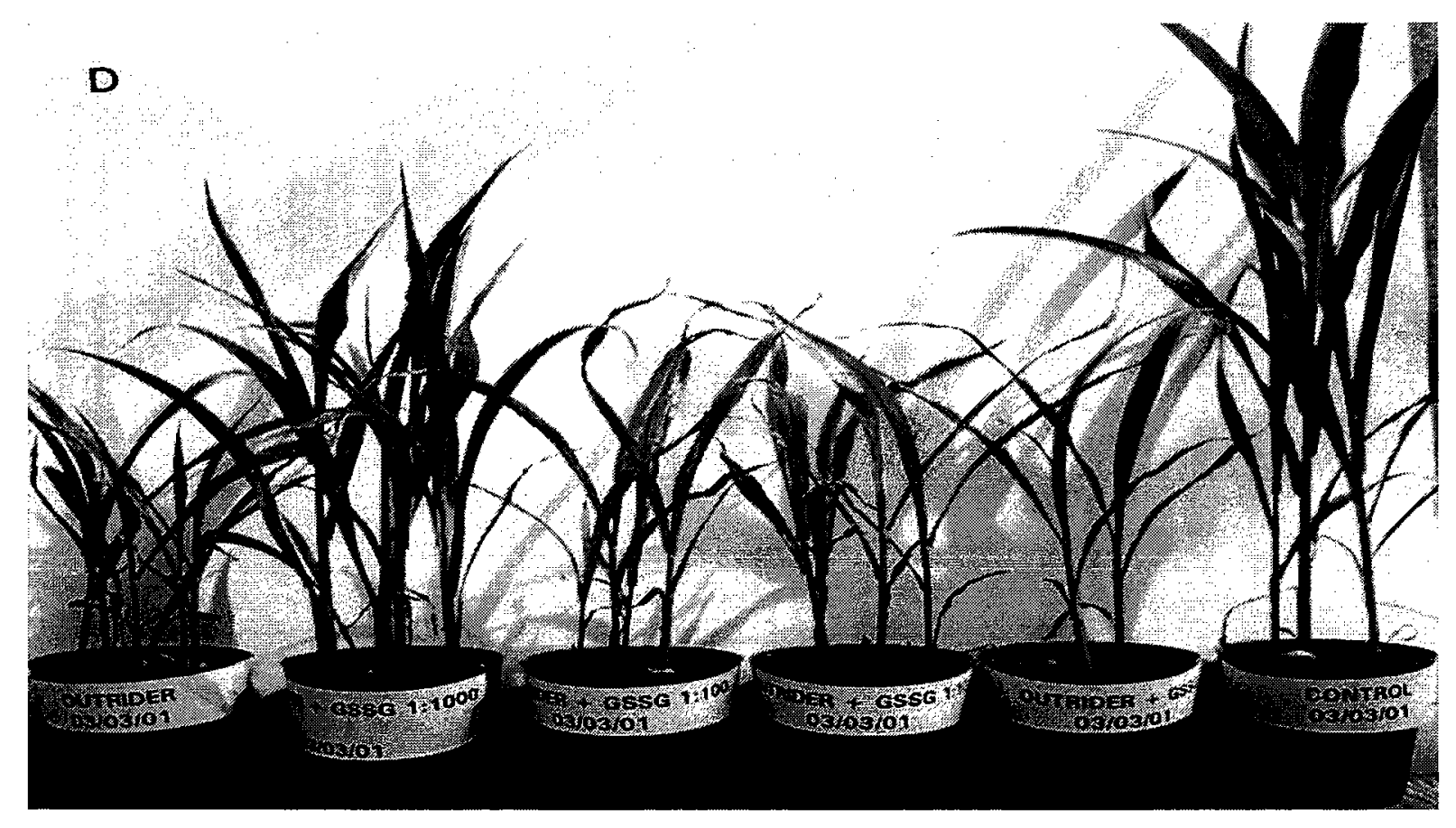

$\begin{array}{ccccc}\begin{array}{c}\text { Outrider } \\ \text { Control }\end{array} & \text { Outrider } & \text { Outrider } & \text { Outrider } & \text { Outrider } \\ & & & & \\ & + \text { GSSG } & + \text { GSSG } & + \text { GSSG } & + \text { GSSG } \\ & 1: 1000 & 1: 100 & 1: 10 & \end{array}$

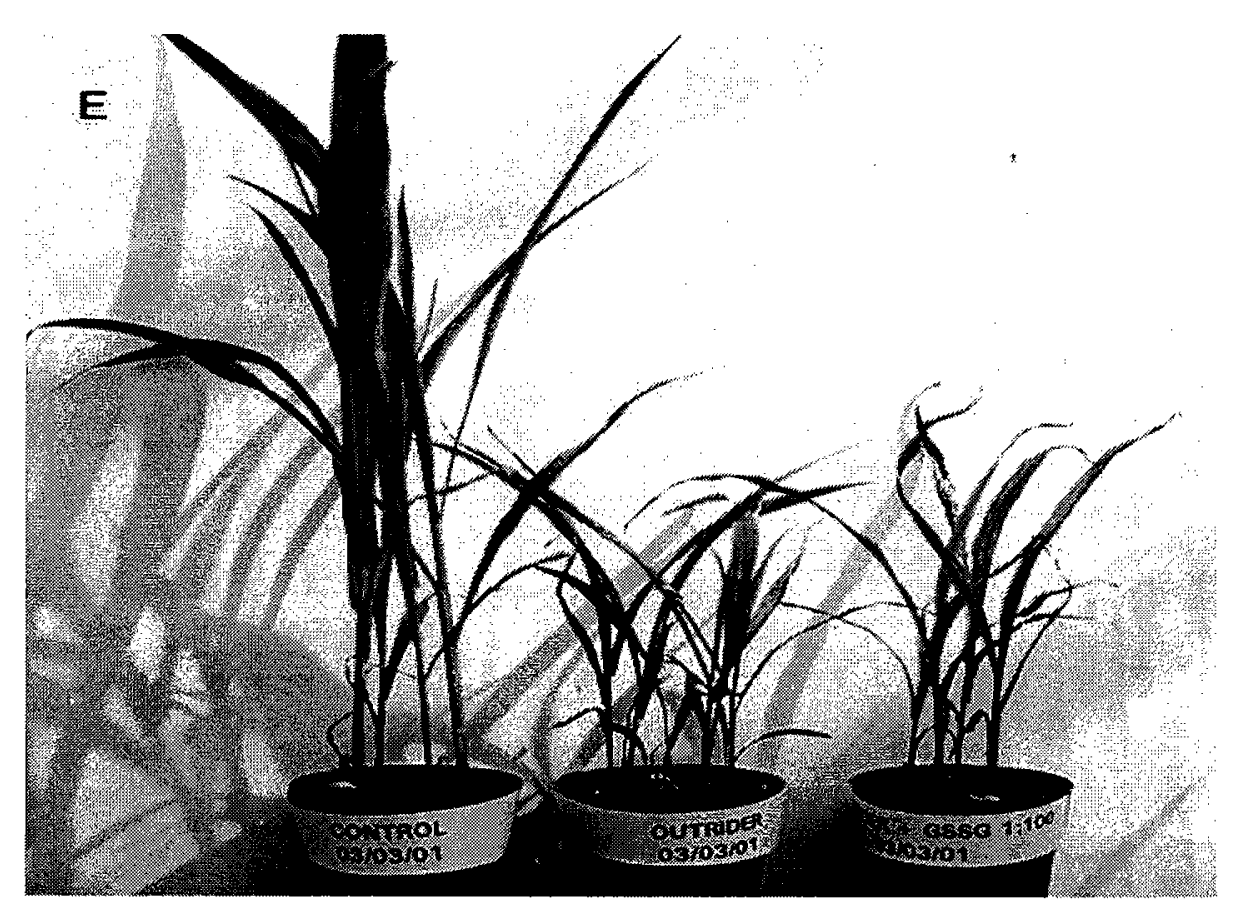

Control

Outrider Outrider + 
GSSG 1:100 
Field Studies with Sorghum (Milo) to Set the Ratio of Outrider and GSSG.

The greenhouse trials of the fall and winter of 2000 and spring of 2001 with sorghum were extended as a series of trials in 2001 at the Purdue University Agronomy Research Center (Agronomy Farm) in July and August of 2001. Plots were $3 \mathrm{ft}^{2}$ and broadcast seeded.

Data collected one or two months following treatment with Outrider constant at $1 \mathrm{oz} / \mathrm{A}$ showed the optimum Outrider-GSSG synergy to be at $0.001 \mathrm{lb} / \mathrm{A}$ GSSG (Figs. 3 and 4). 


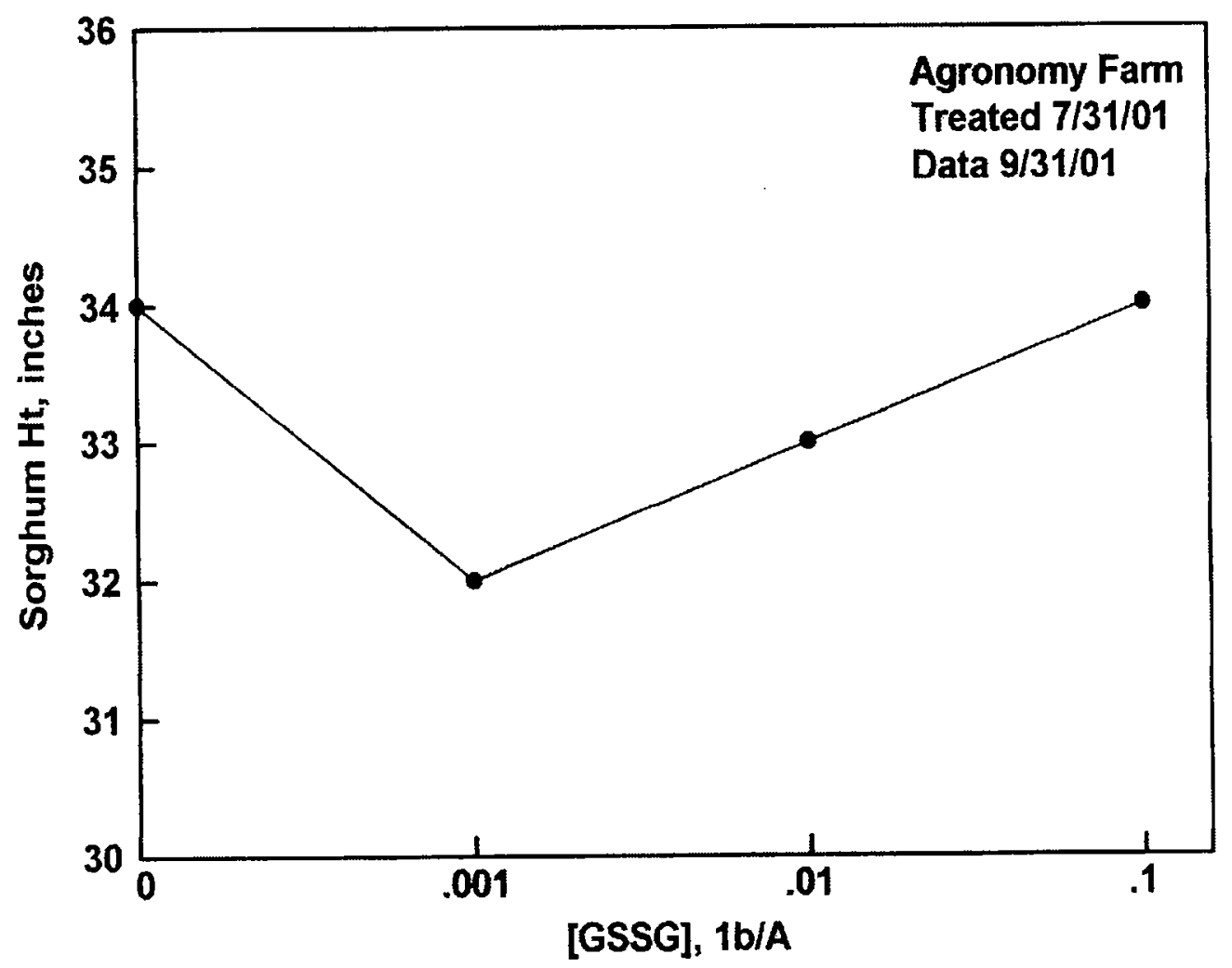

Figure 3. Response of field grown sorghum (milo) to Outrider at $1 \mathrm{oz} / \mathrm{A}(70 \mathrm{~g} / \mathrm{ha})(0 \mathrm{GSSG})$ and Outrider plus the different rates of GSSG (TR-IV) shown on the abscissa (Ib/A $\cong 1 \mathrm{ka} / \mathrm{ha}$. Purdue Agronomy Research Center. Plots $1 \mathrm{~m}^{2}$ broadcast seeded. Treated 7/31/01. Evaluation on 9/31/01. 


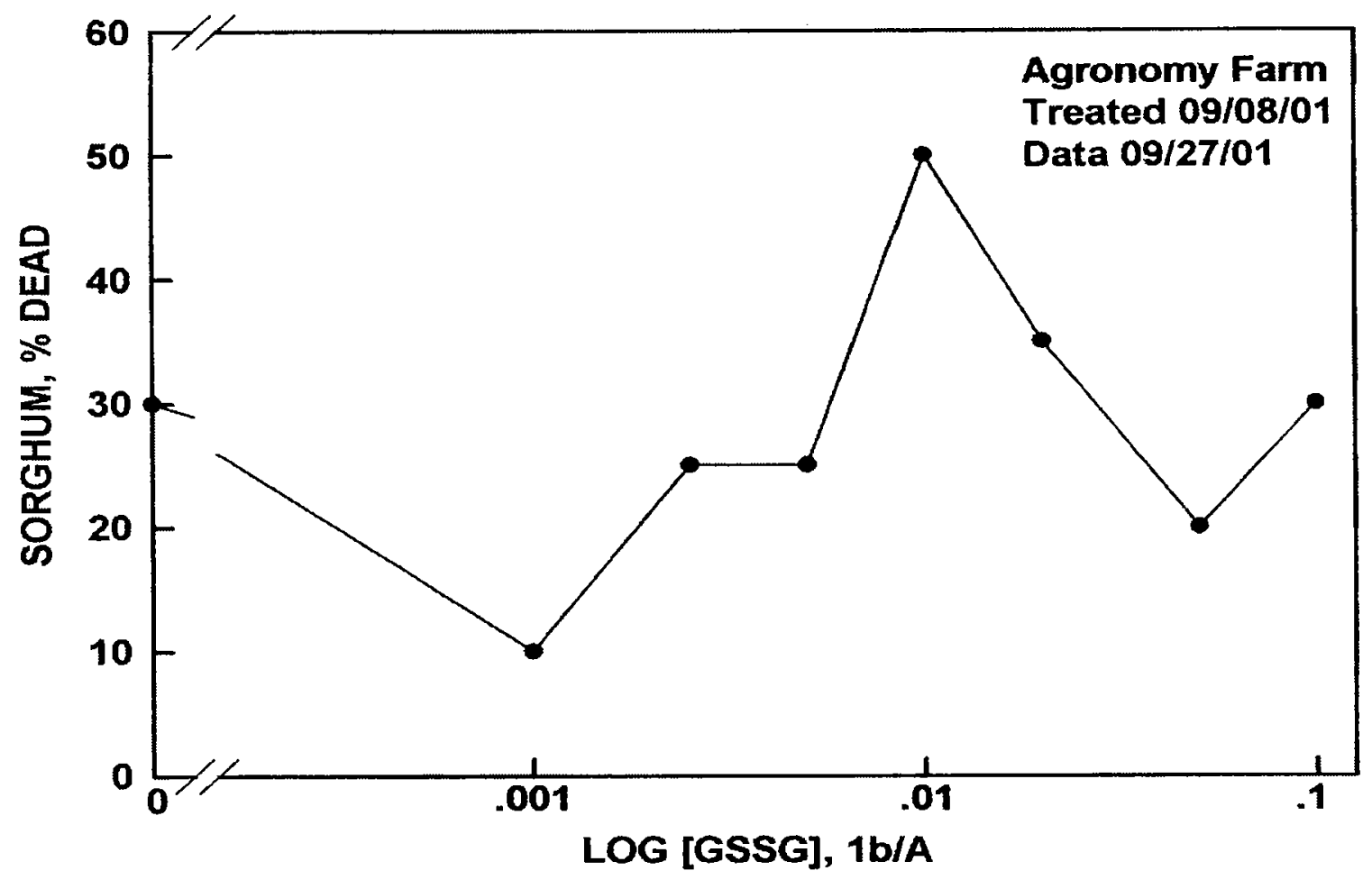

Figure 4. Response of field grown sorghum (Milo) to Outrider at $1 \mathrm{oz} / \mathrm{A}$ (70 $\mathrm{g} / \mathrm{ha}$ ) (O GSSG) and Outrider plus the different rates of GSSG (TR-IV) shown on the abscissa. Purdue Agronomy Research Center. Plots $1 \mathrm{~m}^{2}$ broadcast seeded. Treated 9/08/01. Evaluation on 9/27/01. 


\section{ROADSIDE SMALL PLOT EVALUATIONS 2001-2003.}

The 3 year period between 2001 and 2003 was focused on efforts to establish optimum rates and dates of application as well as to optimize the ratio of Outrider to additive. Several additional additive candidates were identified and evaluated. Thus far, none have proven to be reproducibly effective except for TR-IV. Results are summarized in Table 7 and Figure 5.

\section{1}

In 2001, a total of 40 field trials were established to evaluate the new herbicide mixture comprised of Outrider (Monsanto) and additive TR-IV. The mixture had given eradication of Johnsongrass in single fall and spring applications to regrowth in 1999 and 2000. New field trials in 2001 defined rates and ratios to enhance effectiveness and reduce costs. A second additive designated TR-V, closely related to TR-IV and less expensive to obtain also was evaluated. Compared were different dates of application and growth stages, vegetative, flowering, late mowed vs unmowed, height at the time of treatment, etc. to determine now to best employ the different mixtures and rates of application. Five late field trials just prior to the first killing frost were established as well in Lafayette, Crawfordsville, Logansport and South Bend locations. Major findings were as follow: 1) Growth stage was important. The Johnsongrass must be sprayed when it is $6-9$ inches $(20-30 \mathrm{~cm})$ tall and 2$)$ The optimum ratio was $1 \mathrm{oz} / \mathrm{A}$ (70 $\mathrm{g} / \mathrm{ha}$ ) Outrider $+0.01 \mathrm{~kg} / \mathrm{ha}$ of TR-IV additive.

\section{2}

More than 50 field trials and 3 implementation trials were established for Johnson grass in the period from June 1 to October 20, 2002. In addition to Outrider (Monsanto) and additive TR-IV, seven additional additives identified from laboratory studies were tested in combination with Outrider in an effort to increase efficacy and to reduce costs. Of these seven additives, four were found to be ineffective, one exhibited some promising indications and two will require additional evaluation. Plans are to develop a dosing formula based on Johnson grass height using 2001 and 2002 data with additional data from 2003 to aid future implementation studies planned for 2003.

Rate studies continued to show $1 \mathrm{oz} / \mathrm{A}$ (70 g/ha) to be a practical upper limit for Outrider. When applied to Johnsongrass no more than about 30 inches $(100 \mathrm{~cm})$ tall, control ranged from $50 \%$ to $100 \%$. Most consistent control was achieved during August where control with $1 \mathrm{oz} / \mathrm{A} \mathrm{(70} \mathrm{g/ha)}$ Outrider applied to Johnson grass regrowth after mowing was $80 \pm 15 \%$ when evaluated the year following treatment. The use of the TR-IV additive was essential to consistently achieve Johnson grass eradication. Between 80 and 100\% control was achieved using $1 \mathrm{oz} / \mathrm{A}(70 \mathrm{~g} / \mathrm{ha})$ Outrider $+0.01 \mathrm{~kg} / \mathrm{ha}$ TR-IV. Most consistent results were when applied in August to regrowth after mowing where control was $95 \pm 5 \%$ in all locations throughout the state (northern third, middle third and southern third).

Best results were in mid-June when applied to emerging Johnson grass and in August when applied to regrowth after mowing where control was $95 \pm 5 \%$ in all locations throughout the state (northern third, middle third and southern third). There was no effect of either treatment on Johnson grass much taller than 30 inches $(100 \mathrm{~cm})$ at the time of spraying or of Johnson grass in flower or with seedheads at the time of treatment. A surprising result was the effectiveness of the treatments on regrowth sprayed even in late September or early October (October 10) just a 
few weeks before frost. Preliminary indications are that treatment effectiveness is enhanced if the Johnson grass is mowed between 3 and 4 weeks after treatment. Two new additives were evaluated extensively and with promising outcome. A total of 12 trials have already been established in 4 locations throughout the State. One objective of these new trials is to either reduce the cost of the treatment by $50 \%$ or increase the efficacy by incorporating one or both of these two new additives into the mixture with Outrider and TR-IV.

2003

A total of 46 new trials were established in 2003. Two new additives were evaluated but no improvement over TR-IV was observed. A third new additive has been readied for evaluation in 2004. Two trials in two different locations were established to evaluate the effect of late mowing on treatment efficacy. One trial was mowed early (including the controls which were to have been unmowed and the other trial was lost to early frost). A proposal to create a committed roadside Johnson grass research area with controlled mowing and dates of spraying was prepared for submission to JHRP for consideration.

Development of a formula based on Johnsongrass height from 2001 and 2002 was initiated to predict rates of Outrider-TR-IV required for eradiation of Johnsongrass at different growth stages. 
Table 7. Small plot Johnsongrass evaluations. Primary data before metric conversion, 1999-2002.

\begin{tabular}{|c|c|c|c|c|c|c|c|c|}
\hline Date & Location & $\begin{array}{l}\text { Height } \\
\text { (inches) }\end{array}$ & $\begin{array}{l}\text { Re- } \\
\text { growth }\end{array}$ & Flower & $\begin{array}{l}\text { Oz. } \\
\text { Outrider }\end{array}$ & Control & $\begin{array}{l}\text { Lb. } \\
\text { GSSG }\end{array}$ & Control \\
\hline \multicolumn{9}{|l|}{1999} \\
\hline $10 / 12$ & Columbus & & No & $\begin{array}{l}\text { Late } \\
\text { senescence }\end{array}$ & $\begin{array}{l}0.5 \mathrm{oz} . \\
1.0 \mathrm{oz} .\end{array}$ & $\begin{array}{l}\text { All } \\
\text { controlled }\end{array}$ & & \\
\hline $12 / 27$ & Austin, TX & & No & $\begin{array}{l}\text { Very late } \\
\text { senescence }\end{array}$ & $\begin{array}{l}0.5 \quad \text { oz. } \\
1.0 \mathrm{oz} .\end{array}$ & No control & & \\
\hline \multicolumn{9}{|l|}{2000} \\
\hline $6 / 16$ & Lafayette & $3-5 \mathrm{ft}$. & No & Early bloom & $0.5 \mathrm{oz}$ & No control & & \\
\hline $6 / 21$ & Lafayette & $3 \mathrm{ft}$. & No & No & $0.5 \mathrm{oz}$. & No control & & \\
\hline $7 / 7$ & Lafayette & $2-2.5 \mathrm{ft}$. & Yes & No & $0.5 \mathrm{oz}$ & $\begin{array}{l}2 \mathrm{X}, 4 \mathrm{X}, \\
8 \mathrm{X}, 16 \mathrm{X}, \\
\text { No control }\end{array}$ & & \\
\hline $8 / 18$ & $\begin{array}{l}\text { Crawford- } \\
\text { sville }\end{array}$ & $12 \mathrm{in.}$ & Yes & No & $1 \mathrm{oz}$. & $14 / 41$ & $0.1 \mathrm{lb}$ & $0 / 40$ \\
\hline $9 / 1$ & Lafayette & & & Seed heads & $1 \mathrm{oz}$. & No control & $0.1 \mathrm{lb}$ & $\begin{array}{l}\text { No } \\
\text { control }\end{array}$ \\
\hline \multicolumn{9}{|l|}{2001} \\
\hline $\begin{array}{l}6 / 16 \\
(4)\end{array}$ & $\begin{array}{l}\text { South } \\
\text { Bend }\end{array}$ & $\begin{array}{l}12-14 \\
\text { in. }\end{array}$ & No & No & $1 \mathrm{oz}$. & $7 / 23$ & $\begin{array}{l}0.1 ; 0.01 ; \\
0.001\end{array}$ & $\begin{array}{l}14 / 21 \\
4 / 80 \\
4 / 23\end{array}$ \\
\hline $\begin{array}{l}6 / 16 \\
(5)\end{array}$ & $\begin{array}{l}\text { South } \\
\text { Bend }\end{array}$ & $\begin{array}{l}10-12 \\
\text { in. }\end{array}$ & No & No & $1 \mathrm{oz}$. & $7 / 23 ; 7 / 28$ & $0.1 ; 0.001$ & $\begin{array}{l}14 / 21 \\
10 / 50 \\
4 / 80\end{array}$ \\
\hline $\begin{array}{l}6 / 18 \\
(6)\end{array}$ & $\begin{array}{l}\text { Ellston } \\
\text { Pointe }\end{array}$ & 36 in. & No & No & $1 \mathrm{oz}$ & $1 / 45$ & & \\
\hline $\begin{array}{l}6 / 22 \\
(7)\end{array}$ & $\begin{array}{l}\text { Next to } \\
\text { Green- } \\
\text { house }\end{array}$ & $18 \mathrm{in.}$ & Yes & No & $1 \mathrm{oz}$ & $10 / 20$ & $\begin{array}{l}0.1 ; \\
0.01 ; \\
0.001\end{array}$ & $\begin{array}{l}10 / 88^{\prime} \\
10 / 50 \\
26 / 50\end{array}$ \\
\hline $\begin{array}{l}7 / 12 \\
(14)\end{array}$ & Linden & $36 \mathrm{in}$. & No & $\begin{array}{l}\text { Panicles } \\
\text { emerging }\end{array}$ & $1 \mathrm{oz}$ & $10 / 66$ & $\begin{array}{l}0.1 ; \\
0.01 ; \\
0.001\end{array}$ & $\begin{array}{l}12 / 70 \\
12 / 110 \\
8 / 75\end{array}$ \\
\hline $\begin{array}{l}7 / 13 \\
(16) \\
\end{array}$ & $\begin{array}{l}\text { Samolar } \\
\text { Road }\end{array}$ & $\begin{array}{l}36-38 \\
\text { in. }\end{array}$ & No & No & $1 \mathrm{oz}$ & $0 / 40$ & 0.005 & $2 / 40(0 ?)$ \\
\hline $\begin{array}{l}7 / 26 \\
(17)\end{array}$ & $\begin{array}{l}\text { Sr-25; } \\
\text { Sugar } \\
\text { Creek }\end{array}$ & $6 \mathrm{ft}$. & No & Full flower & $\begin{array}{l}0.5 \mathrm{oz} . \\
1 \mathrm{oz} .\end{array}$ & $\begin{array}{l}\text { No effect } \\
\text { No effect }\end{array}$ & $\begin{array}{l}+0.0005 \\
+0.001\end{array}$ & $\begin{array}{l}\text { No effect } \\
\text { No effect }\end{array}$ \\
\hline $\begin{array}{l}8 / 11 \\
(21)\end{array}$ & $\begin{array}{l}\text { US } 41 \text { in } \\
\text { Kentland }\end{array}$ & 36 in. & No & $\begin{array}{l}\text { Early } \\
\text { anthesis }\end{array}$ & $\begin{array}{l}0.5 \mathrm{oz} . \\
1 \mathrm{oz} .\end{array}$ & No effect & $\begin{array}{l}0.001 / 0.00 \\
5 \\
0.001 / 0.00 \\
01\end{array}$ & No effect \\
\hline
\end{tabular}

$1 \mathrm{oz} / \mathrm{A}=70 \mathrm{~g} / \mathrm{ha} ; 1 \mathrm{lb} / \mathrm{A}=\sim 1 \mathrm{~kg} / \mathrm{ha} ; 1 \mathrm{ft}=\sim 40 \mathrm{~cm}$ 
Table 7. Continued.

\begin{tabular}{|c|c|c|c|c|c|c|c|c|}
\hline Date & Location & $\begin{array}{l}\text { Height } \\
\text { (inches) }\end{array}$ & $\begin{array}{l}\text { Re- } \\
\text { growth }\end{array}$ & Flower & $\begin{array}{l}\text { Oz. } \\
\text { Outrider }\end{array}$ & Control & $\begin{array}{l}\text { Lb. } \\
\text { GSSG }\end{array}$ & Control \\
\hline 2001 & & & & & & & & \\
\hline $\begin{array}{l}8 / 19 \\
(22)\end{array}$ & $\begin{array}{l}\text { IN } 44 \\
\text { Shelby- } \\
\text { ville }\end{array}$ & $20 \mathrm{in.}$ & Yes & No & $1 \mathrm{oz}$. & $6 / 43$ & 0.001 & $2 / 26$ \\
\hline $\begin{array}{l}8 / 27 \\
(23)\end{array}$ & $\begin{array}{l}\text { I-70 West } \\
\text { US } 41 / 150\end{array}$ & $30 \mathrm{in.}$ & Yes & No & $1 \mathrm{oz}$. & $15 / 44$ & $\begin{array}{l}0.1 \\
0.01 \\
0.001 \\
\end{array}$ & $\begin{array}{l}23 / 18 \\
3 / 110 \\
20 / 35 \\
\end{array}$ \\
\hline $\begin{array}{l}8 / 27 \\
(24)\end{array}$ & $\mathrm{I70} \mathrm{W}$ & $31 \mathrm{in.}$ & $\begin{array}{l}\text { Yes (6 } \\
\text { weeks) }\end{array}$ & No & $1 \mathrm{oz}$. & & 0.01 & \\
\hline $\begin{array}{l}8 / 28 \\
(26)\end{array}$ & $\begin{array}{l}\text { US 231 } \\
\text { Romney }\end{array}$ & $36 \mathrm{in.}$ & Yes & Yes & $\begin{array}{l}0.5 \mathrm{oz} \\
1 \mathrm{oz}\end{array}$ & No control & 0.005 & $\begin{array}{l}\text { No } \\
\text { control }\end{array}$ \\
\hline $\begin{array}{l}9 / 1 \\
(27)\end{array}$ & South Bend & $\begin{array}{l}18-20 \\
\text { in. }\end{array}$ & Yes & No & $1 \mathrm{oz}$ & & $\begin{array}{l}0.1 \\
0.01 \\
0.001 \\
\end{array}$ & \\
\hline $\begin{array}{l}9 / 7 \\
(28)\end{array}$ & South Bend & $3-4 \mathrm{ft}$. & No & Full flower & $\begin{array}{l}0.5 \mathrm{oz} . \\
1.0 \mathrm{oz}\end{array}$ & No control & $\begin{array}{l}0.01 \\
0.005 \\
0.0025\end{array}$ & $\begin{array}{l}\text { No } \\
\text { control }\end{array}$ \\
\hline $\begin{array}{l}9 / 7 \\
(29)\end{array}$ & $\begin{array}{l}\text { ST } 25 ; \mathrm{N} \text { of } \\
\text { Laf. }\end{array}$ & $24 \mathrm{in.}$ & Yes & No & $1 \mathrm{oz}$. & $100 \%$ & $\begin{array}{l}0.01 \\
0.001 \\
\end{array}$ & $100 \%$ \\
\hline $\begin{array}{l}9 / 15 \\
(34)\end{array}$ & SR 25 & $36 \mathrm{in}$. & Yes & $\begin{array}{l}\text { Early } \\
\text { anthesis }\end{array}$ & $1 \mathrm{oz}$. & $\sim 70 \%$ & 0.01 & $\begin{array}{l}1 / 2 X \\
5 / 25 ; 3 \\
X ; 1 X \\
10 / 20 ; 2 \\
X, 1 / 16\end{array}$ \\
\hline $\begin{array}{l}10 / 3 \\
(38)\end{array}$ & SR 25 & $\begin{array}{l}23-30 \\
\text { in. }\end{array}$ & Yes & No & $1 \mathrm{oz}$. & $4 / 8$ & $\begin{array}{l}0.01 \\
0.001\end{array}$ & $\begin{array}{l}4 / 8 \\
4 / 9 \\
\text { Freeze } \\
\text { Oct. }\end{array}$ \\
\hline $10 / 19$ & $\begin{array}{l}\text { Crawfords- } \\
\text { ville }\end{array}$ & $22 \mathrm{in.}$ & Yes & No & $1 \mathrm{oz}$. & No control & 0.01 & $\begin{array}{l}\text { No } \\
\text { control } \\
\text { Tips } \\
\text { frozen }\end{array}$ \\
\hline \multicolumn{9}{|l|}{2002} \\
\hline $\begin{array}{l}6 / 3 \\
(2) \\
\end{array}$ & $\begin{array}{l}\text { US 44E } \\
\text { Shelbyville }\end{array}$ & 16 in. & No & No & $1 \mathrm{oz}$. & No data & 0.01 & No data \\
\hline $\begin{array}{l}6 / 3 \\
(3) \\
\end{array}$ & $\begin{array}{l}\text { US } 44 \text { E } \\
\text { Shelbyville }\end{array}$ & $16 \mathrm{in.}$ & No & No & $1 \mathrm{oz}$ & No data & 0.01 & No data \\
\hline $\begin{array}{l}6 / 6 \\
(3)\end{array}$ & $\begin{array}{l}\text { Green- } \\
\text { house } \\
\text { Lafayette }\end{array}$ & $18 \mathrm{in}$. & Yes & No & $1 \mathrm{oz}$ & No kill & 0.01 & No kill \\
\hline $\begin{array}{l}6 / 8 \\
(5) \\
\end{array}$ & South Bend & $6-15$ in. & No & No & $\begin{array}{l}1 \mathrm{oz} . \\
0.5 \mathrm{oz} .\end{array}$ & $\begin{array}{l}1 / 12 \\
5 / 20 \\
\end{array}$ & 0.005 & $6 / 26$ \\
\hline $\begin{array}{l}6 / 8 \\
(6) \\
\end{array}$ & South Bend & $9-12$ in. & No & No & $1 \mathrm{oz}$. & No control & 0.01 & $\begin{array}{l}\text { No } \\
\text { control }\end{array}$ \\
\hline
\end{tabular}


Table 7. Continued.

\begin{tabular}{|c|c|c|c|c|c|c|c|c|}
\hline Date & Location & $\begin{array}{l}\text { Height } \\
\text { (inches) }\end{array}$ & $\begin{array}{l}\text { Re- } \\
\text { growth }\end{array}$ & Flower & $\begin{array}{l}\text { Oz. } \\
\text { Outrider }\end{array}$ & Control & $\begin{array}{l}\text { Lb. } \\
\text { GSSG }\end{array}$ & Control \\
\hline $\begin{array}{l}6 / 13 \\
(8)\end{array}$ & $\begin{array}{l}\text { I70 Terre } \\
\text { Haute; US } \\
41 / \text { US } 150\end{array}$ & $\begin{array}{l}18-24 \\
\text { in. }\end{array}$ & Yes & No & $1 \mathrm{oz}$. & $100 \%$ & 0.01 & $100 \%$ \\
\hline $\begin{array}{l}6 / 14 \\
(10)\end{array}$ & $\begin{array}{l}\text { US 40 } \\
\text { Brazil }\end{array}$ & $8-30$ in. & Yes & No & $1 \mathrm{oz}$. & $\begin{array}{ll}17 & \\
7 & 60 \%\end{array}$ & 0.01 & $\begin{array}{ll}5 & 0 \\
3 & 0 \\
& 7 \\
& 72 \%\end{array}$ \\
\hline $\begin{array}{l}6 / 18 \\
(11)\end{array}$ & $\begin{array}{l}\text { US } 231 \\
\text { Linden }\end{array}$ & $\begin{array}{l}12-14 \\
\text { in. }\end{array}$ & Yes & No & $1 \mathrm{oz}$. & $22 / 32$ & 0.01 & $15 / 32$ \\
\hline $\begin{array}{l}6 / 19 \\
(12)\end{array}$ & SR 25 & 20 in. & Yes & No & $1 \mathrm{oz}$ & & 0.01 & \\
\hline $\begin{array}{l}6 / 22 \\
(13)\end{array}$ & Taos, MO & $18 \mathrm{in.}$ & Yes & No & $1 \mathrm{oz}$. & $2 / 12$ & 0.01 & $\begin{array}{l}0 / 12 \\
100 \%\end{array}$ \\
\hline $\begin{array}{l}6 / 22 \\
(14)\end{array}$ & Taos, MO & $10 \mathrm{in.}$ & Yes & No & $1 \mathrm{oz}$. & $100 \%$ & 0.01 & $100 \%$ \\
\hline $\begin{array}{l}6 / 30 \\
(15)\end{array}$ & $\begin{array}{l}\text { Sosby } \\
\text { Truck Stop }\end{array}$ & $\begin{array}{l}30-36 \\
\text { in. }\end{array}$ & Yes & Yes & $1 \mathrm{oz}$. & No kill & 0.01 & No kill \\
\hline $\begin{array}{l}7 / 15 \\
(16 / \\
17) \\
\end{array}$ & US $231 \mathrm{~S}$ & $30 \mathrm{in.}$ & Yes & No & $\begin{array}{l}0.5 \mathrm{oz} . \\
1.0 \mathrm{oz}\end{array}$ & $\begin{array}{l}12 / 60 \\
15 / 100\end{array}$ & $\begin{array}{l}0.0025 \\
0.005\end{array}$ & $\begin{array}{l}1 / 80 \\
1 / 40\end{array}$ \\
\hline $\begin{array}{l}8 / 1 \\
(18 / \\
19)\end{array}$ & South Bend & $\begin{array}{l}12-18 \\
\text { in. }\end{array}$ & Yes & No. & $\begin{array}{l}0.5 \mathrm{oz} . \\
1.0 \mathrm{oz} .\end{array}$ & & $\begin{array}{l}0.005 \\
0.01\end{array}$ & \\
\hline $\begin{array}{l}8 / 1 \\
(20 / \\
21)\end{array}$ & $\mathrm{IN} 25 \mathrm{~N}$ & $\begin{array}{l}30-46 \\
\text { in. }\end{array}$ & No & Yes & $\begin{array}{l}0.5 \mathrm{oz} . \\
1.0 \mathrm{oz}\end{array}$ & $\begin{array}{l}1 / 150 \\
22 / 50\end{array}$ & $\begin{array}{l}0.005 \\
0.01\end{array}$ & $\begin{array}{l}2 / 34 \\
1 / 20\end{array}$ \\
\hline $\begin{array}{l}8 / 1 \\
(22)\end{array}$ & South Bend & $\begin{array}{l}10-12 \\
\text { in. }\end{array}$ & Yes & No & $1 \mathrm{oz}$. & $6 / 8$ & 0.01 & $6 / 18$ \\
\hline $\begin{array}{l}8 / 1 \\
(23) \\
\end{array}$ & IN 25 & 36 in. & Yes & No & $1 \mathrm{oz}$. & $4 / 7$ & 0.01 & $0 / 10$ \\
\hline $\begin{array}{l}8 / 22 \\
(24- \\
20) \\
\end{array}$ & South Bend & $\begin{array}{l}\text { 14-26 } \\
\text { in. }\end{array}$ & Yes & No & $\begin{array}{l}0.5 \mathrm{oz} . \\
1.0 \mathrm{oz}\end{array}$ & $\begin{array}{l}\text { No data } \\
\text { No JG }\end{array}$ & $\begin{array}{l}0.005 \\
0.01\end{array}$ & $\begin{array}{l}\text { No data } \\
\text { No JO }\end{array}$ \\
\hline $\begin{array}{l}8 / 22 \\
(27)\end{array}$ & South Bend & $\begin{array}{l}10-12 \\
\text { in. }\end{array}$ & Yes & No & $1 \mathrm{oz}$. & $100 \%$ & 0.01 & $100 \%$ \\
\hline $\begin{array}{l}9 / 3 \\
(28- \\
29 \\
30) \\
\end{array}$ & US $231 \mathrm{~N}$ & $\begin{array}{l}32-36 \\
\text { in. }\end{array}$ & Yes & No & $\begin{array}{l}0.5 \mathrm{oz} . \\
1.0 \mathrm{oz} .\end{array}$ & $\begin{array}{l}4 / 20 \\
10 / 45\end{array}$ & $\begin{array}{l}0.005 \\
0.01\end{array}$ & $\begin{array}{l}0 / 12 \\
\text { Mowed } \\
0 / 45 \\
10 / 7 / 02\end{array}$ \\
\hline $\begin{array}{l}9 / 3 \\
(31)\end{array}$ & US $231 \mathrm{~N}$ & $\begin{array}{l}32-36 \\
\text { in. }\end{array}$ & Yes & Yes & $1 \mathrm{oz}$. & $5 / 30$ & 0.01 & $\begin{array}{l}2 / 30 \\
\text { Mowed } \\
10 / 7 / 02\end{array}$ \\
\hline
\end{tabular}


Table 7. Continued.

\begin{tabular}{|c|c|c|c|c|c|c|c|c|}
\hline Date & Location & $\begin{array}{l}\text { Height } \\
\text { (inches) }\end{array}$ & $\begin{array}{l}\text { Re- } \\
\text { growth }\end{array}$ & Flower & $\begin{array}{l}\text { Oz. } \\
\text { Outrider }\end{array}$ & Control & $\begin{array}{l}\text { Lb. } \\
\text { GSSG }\end{array}$ & Control \\
\hline $\begin{array}{l}9 / 3 \\
(32)\end{array}$ & $\begin{array}{l}\text { Truck } \\
\text { Mounted US } \\
231 \mathrm{~N}\end{array}$ & $\begin{array}{l}20-26 \\
\text { in. }\end{array}$ & Yes & No & $1 \mathrm{oz}$. & $\begin{array}{l}4 / 22 \\
1 / 20\end{array}$ & 0.01 & $8 / 100$ \\
\hline $\begin{array}{l}9 / 16 \\
(33)\end{array}$ & Seymour & 30 in. & Yes & No & $1 \mathrm{oz}$ & $\begin{array}{l}\text { Est. 20- } \\
35 \%\end{array}$ & 0.01 & $\begin{array}{l}\text { Est. 45- } \\
55 \%\end{array}$ \\
\hline $\begin{array}{l}9 / 6 \\
(34, \\
35, \\
36)\end{array}$ & SR 25 & 24 in. & Yes & $\begin{array}{l}\text { Early } \\
\text { anthesis }\end{array}$ & $\begin{array}{l}0.5 \mathrm{oz} \\
1 \mathrm{oz} .\end{array}$ & $100 \%$ & $\begin{array}{l}0.005 \\
0.01\end{array}$ & $\begin{array}{l}100 \% \\
\text { mowed } \\
9 / 25 / 02\end{array}$ \\
\hline $\begin{array}{l}9 / 6 \\
(37)\end{array}$ & SR 25 & 26 in. & Yes & $\begin{array}{l}\text { Early } \\
\text { anthesis }\end{array}$ & $1 \mathrm{oz}$ & $100 \%$ & 0.01 & $\begin{array}{l}100 \% \\
\text { mowed } \\
10 / 13 / 02\end{array}$ \\
\hline $\begin{array}{l}9 / 13 \\
(38) \\
\end{array}$ & US $231 \mathrm{~S}$ & $30 \mathrm{in.}$ & Yes & Yes & $1 \mathrm{oz}$. & & 0.01 & Mowed \\
\hline $\begin{array}{l}9 / 15 \\
(39, \\
40, \\
41)\end{array}$ & Linden II & $\begin{array}{l}\text { 16-18 } \\
\text { in. }\end{array}$ & Yes & No & $\begin{array}{l}0.5 \mathrm{oz} \\
1.0 \mathrm{oz}\end{array}$ & $\begin{array}{l}5 / 19 \\
12 / 36\end{array}$ & $\begin{array}{l}0.005 \\
0.01\end{array}$ & $\begin{array}{l}4 / 14 \quad 3 \mathrm{X} \\
3 / 194 \mathrm{X} \\
100 \%\end{array}$ \\
\hline $\begin{array}{l}9 / 26 \\
(42)\end{array}$ & $\begin{array}{l}\text { Crawfords- } \\
\text { ville }\end{array}$ & 22 in. & Yes & $\begin{array}{l}\text { Seed head } \\
\text { in nest to } \\
\text { fully } \\
\text { emerged }\end{array}$ & $1 \mathrm{oz}$. & No control & 0.01 & $\begin{array}{l}\text { No } \\
\text { control }\end{array}$ \\
\hline $\begin{array}{l}9 / 26 \\
(43, \\
44)\end{array}$ & $\begin{array}{l}\text { Crawfords- } \\
\text { ville }\end{array}$ & 22 in. & Yes & $\begin{array}{l}\text { Same as } \\
9 / 26(42)\end{array}$ & $\begin{array}{l}0.5 \mathrm{oz} \\
1.0 \mathrm{oz}\end{array}$ & $\begin{array}{l}\text { Only } \\
\text { mixture } \\
\text { applied } \rightarrow\end{array}$ & $\begin{array}{l}0.005 \\
0.01\end{array}$ & $\begin{array}{l}\text { No } \\
\text { control }\end{array}$ \\
\hline $\begin{array}{l}9 / 27 \\
(45)\end{array}$ & $\begin{array}{l}\text { Greenhouse } \\
\text { Lafayette }\end{array}$ & $3-4 \mathrm{ft}$. & Yes & Set seed & $1 \mathrm{oz}$ & No control & 0.01 & $\begin{array}{l}\text { No } \\
\text { control }\end{array}$ \\
\hline $\begin{array}{l}9 / 28 \\
(46)\end{array}$ & $\begin{array}{l}\text { Old Romney } \\
\text { Road }\end{array}$ & $\begin{array}{l}10-12 \\
\text { in. }\end{array}$ & Yes & No & $1 \mathrm{oz}$. & $\begin{array}{l}\text { No } \\
\text { regrowth }\end{array}$ & 0.01 & $\begin{array}{l}\text { No } \\
\text { regrowth }\end{array}$ \\
\hline $\begin{array}{l}10 / 8 \\
(47, \\
48, \\
49) \\
\end{array}$ & US 40 West & $\begin{array}{l}15-18 \\
\text { in. }\end{array}$ & Yes & No & $\begin{array}{l}0.5 \\
1.0\end{array}$ & $\begin{array}{l}11 / 39 \\
0 / 22\end{array}$ & $\begin{array}{l}0.005 \\
0.01\end{array}$ & $\begin{array}{l}4 / 15 \\
0 / 12 \\
10 / 20 \\
\text { frozen }\end{array}$ \\
\hline $\begin{array}{l}10 / 8 \\
(50)\end{array}$ & $\begin{array}{l}\text { Crawfords- } \\
\text { ville }\end{array}$ & 36 in. & Yes & $\begin{array}{l}\text { Flowered } \\
\& \text { set seed }\end{array}$ & $1 \mathrm{oz}$. & $40 / 46$ & 0.01 & $\begin{array}{l}10 / 33 \\
\text { Mowed } \\
10 / 19\end{array}$ \\
\hline
\end{tabular}




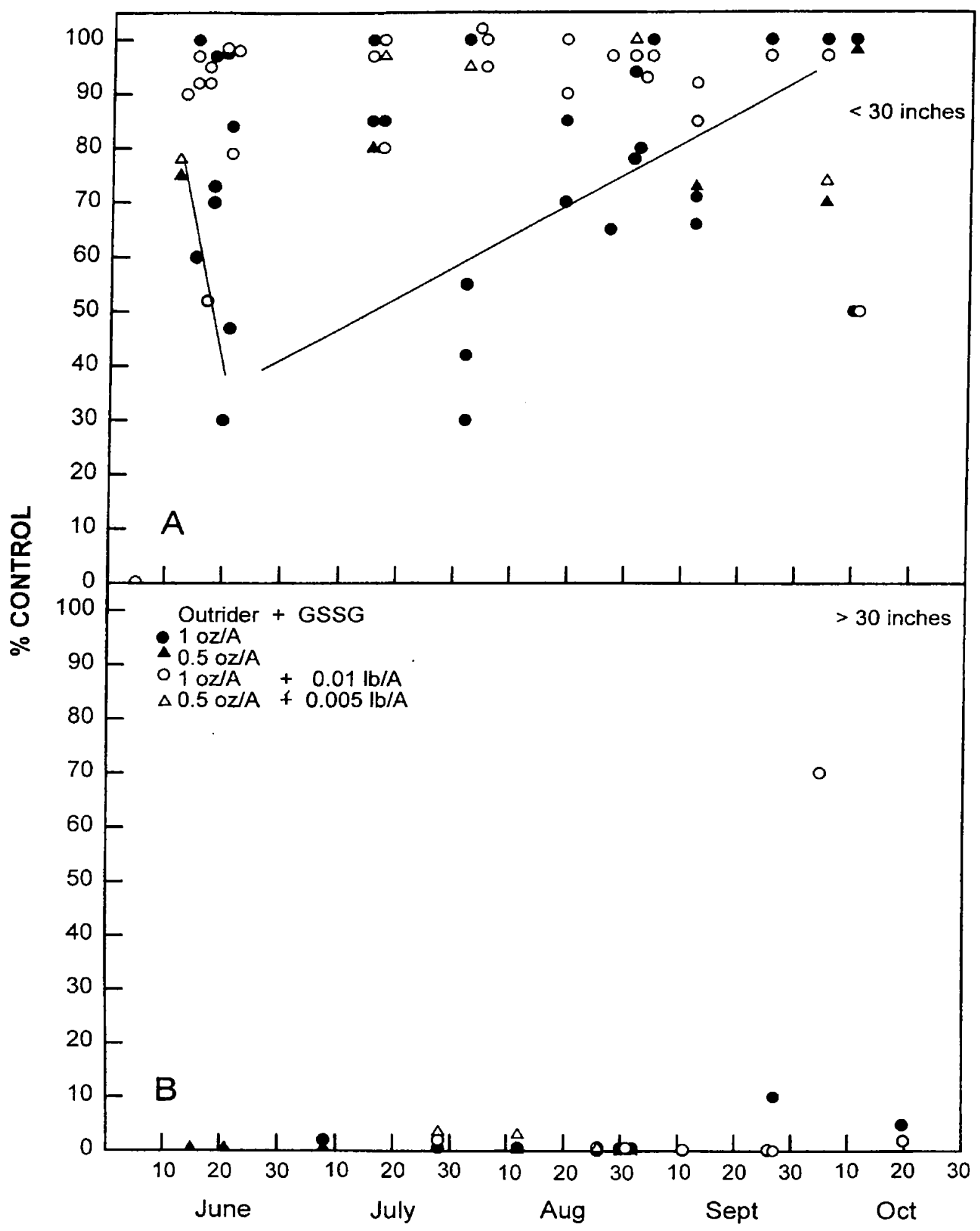

Figure 5. Graphic summary of data of Table 7 showing percent control of Johnsongrass vs date of application. A. Johnsongrass $<30$ inches $(70 \mathrm{~cm})$ tall at time of spraying. B. With Johnsongrass $>30$ inches $(70 \mathrm{~cm})$ at the time of spray. None of the treatments were effective. For metric 
conversions, see p. 24. 
Final evaluations of 2003 trials cannot be completed until there is an opportunity to evaluate regrowth in late June and July of 2004. The need to evaluate regrowth to determine treatment efficacy is one of the complicating features of research on Johnsongrass control. In most situations the research is on a 2 to 4 year cycle for any particular treatment. The treatment is applied in year 1 and regrowth evaluated in year 2 . If extensive modifications are required, it may be year 3 before the new combination is applied with final evaluation in year 4 . Thus, in a 5 year project, not more than two full rounds of evaluation can be completed once a promising treatment is identified.

Table 8. Fescue trial with Outrider and Outrider plus GSSG or GSH. Applied September 16, 2000 .

\begin{tabular}{ccccc}
\hline Outrider $^{*}$ & GSSG & GSH & X-74 & Seedheads $/ 0.17 \mathrm{~m}^{2}$ \\
\hline $1 \mathrm{oz} / \mathrm{A}$ & $0.1 \mathrm{~kg} / \mathrm{ha}$ & - & $0.25 \%$ & 56 \\
- & $0.1 \mathrm{~kg} / \mathrm{ha}$ & - & $0.25 \%$ & 95 \\
$1 \mathrm{oz} / \mathrm{A}$ & & $0.1 \mathrm{~kg} / \mathrm{ha}$ & $0.25 \%$ & 36 \\
$1 \mathrm{oz} / \mathrm{A}$ & - & - & $0.25 \%$ & 50 \\
- & - & $0.1 \mathrm{~kg} / \mathrm{ha}$ & $0.25 \%$ & 40 \\
- & - & - & $0.25 \%$ & 96 \\
\hline
\end{tabular}

*70 g/ha

Assessment of injury to fescue.

Beginning in 2000, a series of trials were conducted to evaluate the injury to fescue if any resulting from Outrider or Outrider plus TR-IV applications. Typical data are given in Table 8 from 2000. Fescue growth may have been temporarily slowed following application with up to a $50 \%$ reduction in seedheads in the next season but no consequential effects on fescue viability were observed as a result of Outrider or Outrider plus TR-IV applications.

\section{1-2003 ROADSIDE IMPLEMENTATION TRIALS}

Research and implementation activities related to Johnsongrass control were based on large scale test plot results. A mixture of $1 \mathrm{oz} / \mathrm{A}(70 \mathrm{~g} / \mathrm{ha})$ Outrider plus 0.01 or $0.001 \mathrm{~kg} / \mathrm{ha}$ of a new additive TR-IV eradicated Johnsongrass when applied to Johnsongrass 12-36 inches $(40-120 \mathrm{~cm})$ tall prior to flowering. We estimate that at current prices, Johnsongrass eradication can be provided to the districts at a cost of materials of about $\$ 40 /$ acre $(\$ 100 /$ ha). Three implementation trials were carried out in the Crawfordsville district, one in the fall of 2001 and two in the spring of 2002. Two additional implementation trials were completed in the fall of 2002, one in the Crawfordsville District and one in the Seymour District. 
One additional implementation trial was carried out in 2003. Despite numerous attempts, we have only limited implementation data for the Outrider-TR-IV mixture for Johnsongrass eradication uncomplicated by inadvertent mowing or spraying with Roundup by state maintenance crews or mowing or spraying with Roundup by adjacent land owners (getting permission to treat and asking them not to spray only worsened the situation).

2001

Meetings and correspondence were continued with Monsanto personnel to discuss implementation of the sulfonylurea additive mixture. Materials were obtained for a first implementation trial with Outrider comparing TR-IV and TR-V additives in August. The trial was located on I-70 E and W between Junction SR 46 and SR 41 near Terre Haute. Applications used Swinglok equipment provided by the Crawfordsville Subdistrict and were applied by Dave Sosby. Preliminary findings suggest control comparable to that observed with small plots (Figure 6).

The spring evaluation of the plots on I-70 applied with INDOT truck-mounted equipment found virtually no Johnsongrass remaining in plots $B, C$. and D of the experiment designated 01-24 applied westbound. There were the $1 \mathrm{oz} / \mathrm{A}$ Outrider-GSSG combinations at all three rates of $0.001,0.01$ and $0.1 \mathrm{~kg} / \mathrm{ha}$ of GSSG. There was only minimal control with $2 \mathrm{oz} / \mathrm{A}$ of Outrider alone. Control in the 01-25 series with 2 oz/A Outrider plus the $0.001,0.01$ or $0.1 \mathrm{~kg} / \mathrm{ha}$ rates of GSH was minimal to none. The entire experiment was evaluated on foot. Two areas were located to verify both from photographs and from residual culms from last year's growth where there had been substantial Johnsongrass infestations in 2001 but which failed to regrow in 2002. In the unmowed, unsprayed check areas, the regrowth was approaching $3 \mathrm{ft}$ in height. The Johnsongrass east bound was taller at the time of spraying. We cannot discount this as a factor. 
Figure 6

Johnsongrass Implementation Trial

I-70 $\mathrm{E}$ and W Beginning on I-70 E

0.25 miles West of SR-46

Sprayed: $8 / 27 / 01$

Swinglok equipment from Crawfordsville Subdistrict

$25 \mathrm{gpa}(230 \mathrm{l} / \mathrm{ha})$

All treatments contained 1.1 gal X-77 surfactant/50 gal water (4 1/460 1 water)

Photographed 10/19/01

Mowed (completion date) 9/17/01

Sprayed regrowth from mid-July mowing (ca. 6 weeks of regrowth). Mean height 31 in (110 $\mathrm{cm}$ )

The most promising treatment appeared to be:

$1 \mathrm{oz} / \mathrm{A}(70 \mathrm{~g} / \mathrm{ha})$ Outrider $+0.01 \mathrm{lb} / \mathrm{A}(0.01 \mathrm{~kg} / \mathrm{ha}) \mathrm{GSSG}$ (in agreement with small plot trials)

$1 \mathrm{oz} / \mathrm{A}=70 \mathrm{~g} / \mathrm{ha}$

$1 \mathrm{lb} / \mathrm{A}=\sim 1 \mathrm{~kg} / \mathrm{ha}$ 


\section{RESPONSE OF FESCUE TO OUTRIDER + GSSG BUT NOT OUTRIDER + GSSG}

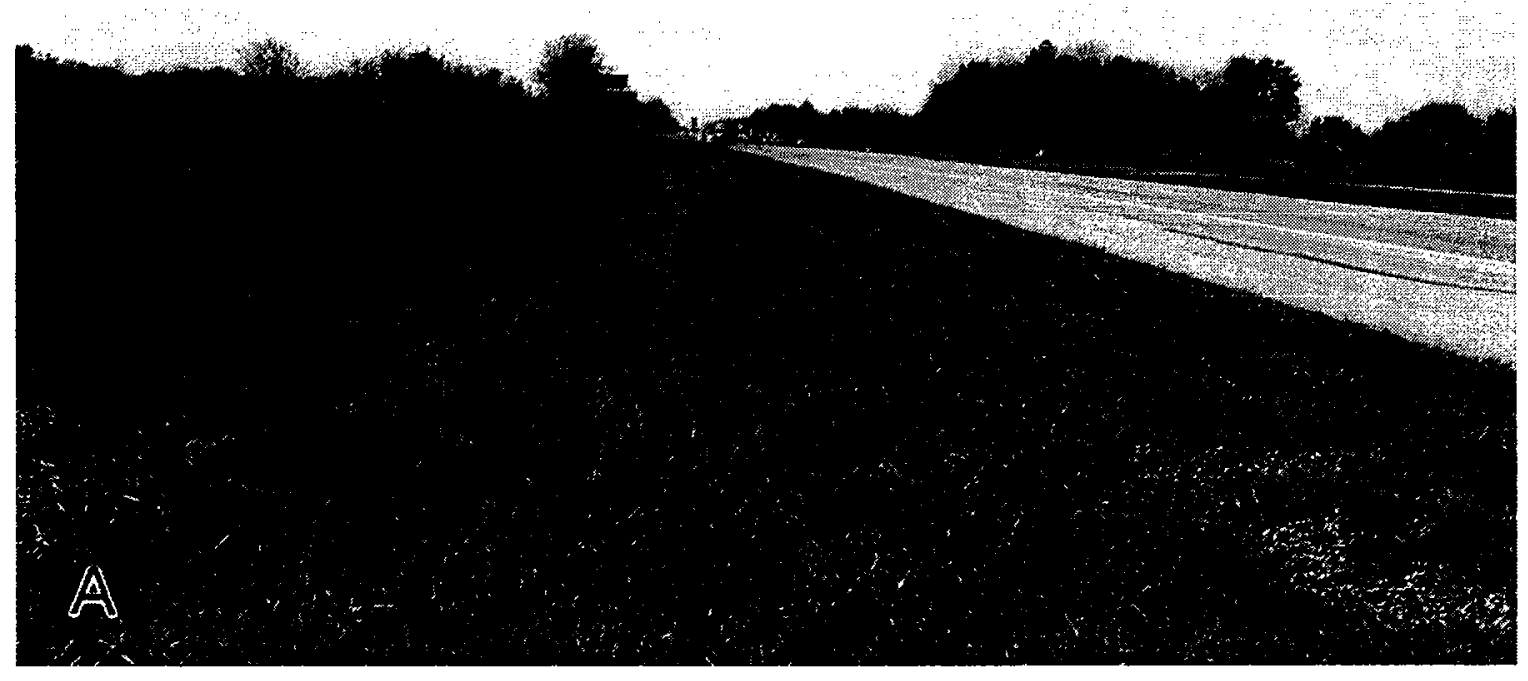

\section{Unsprayed check}

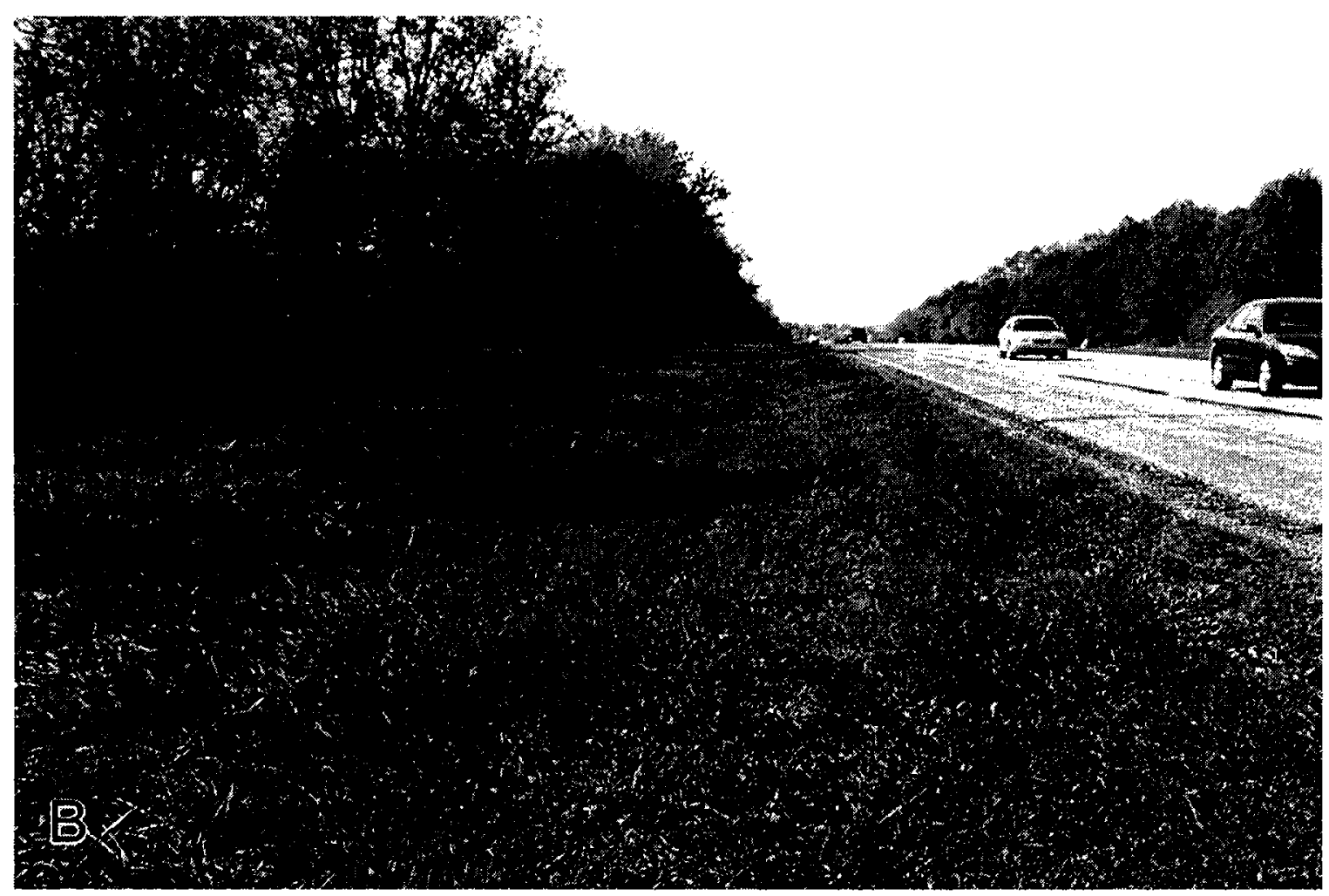


Treatment A. 1 oz/A Outrider 


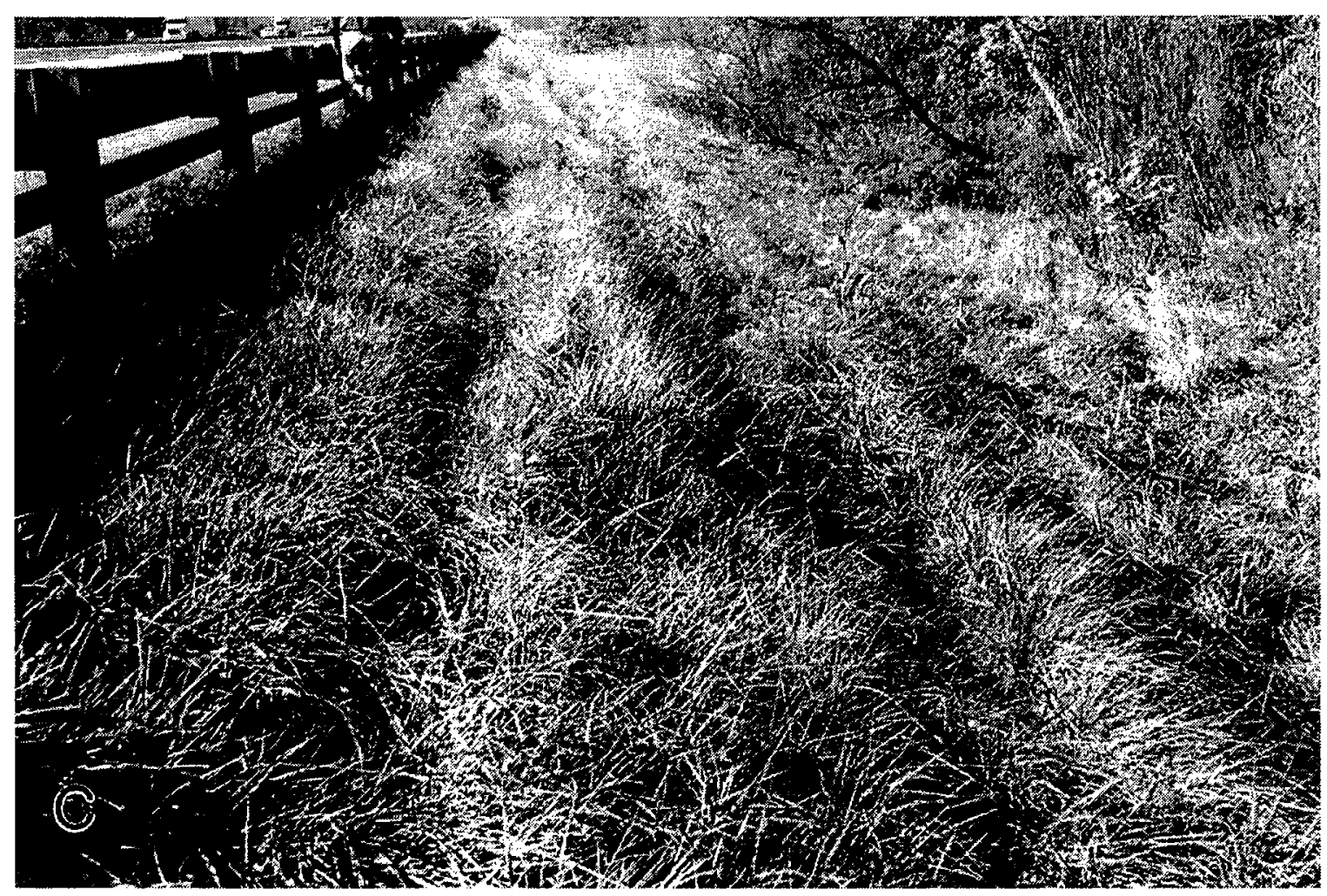

$1 \mathrm{oz} / \mathrm{A}$ Outrider $+0.001 \mathrm{lb} / \mathrm{A}$ GSSG. Injury to fescue visibly

enhanced.

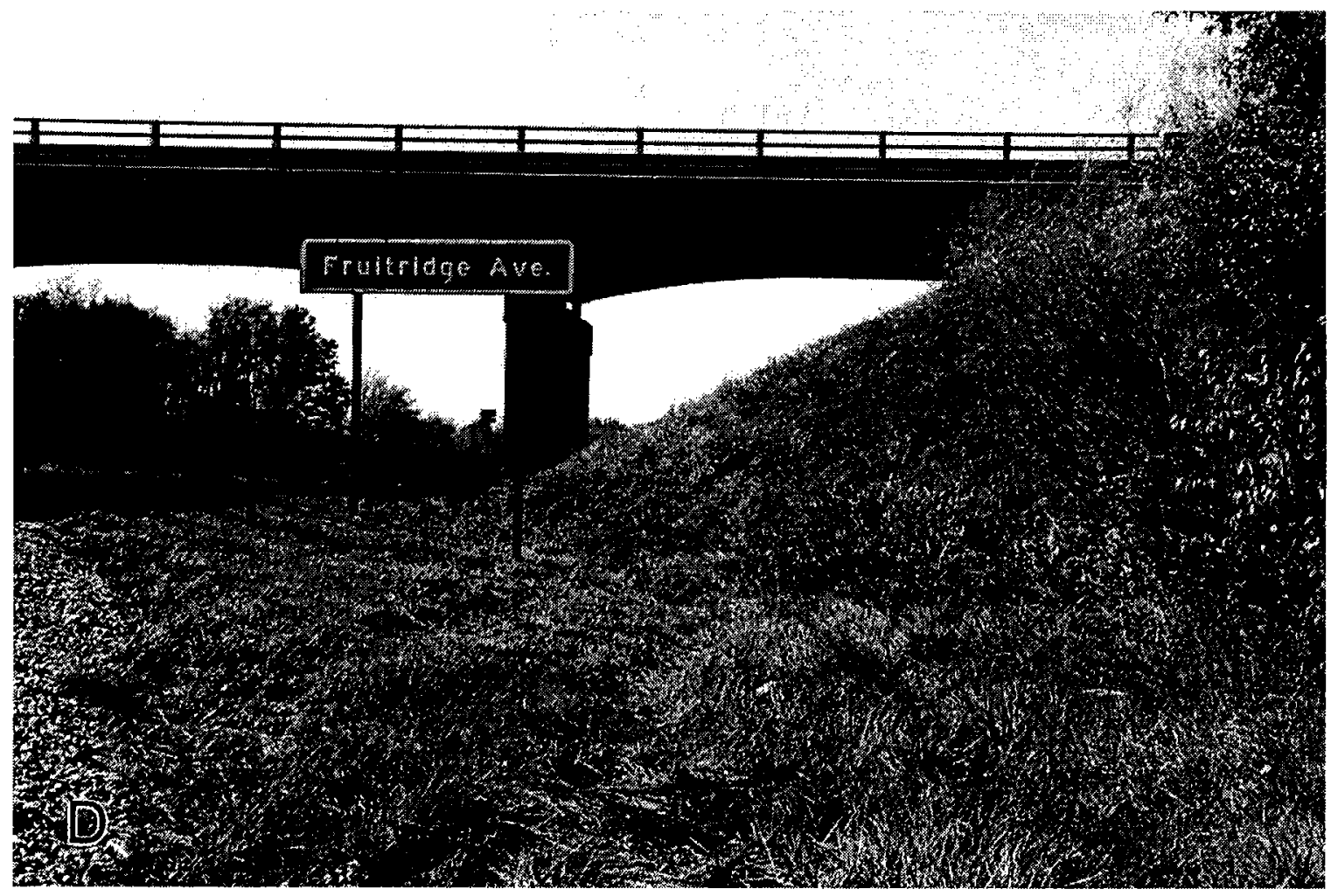


$1 \mathrm{oz} / \mathrm{A}$ Outrider $+0.01 \mathrm{lb} / \mathrm{A}$ GSSG. Injury to fescue visibly

enhanced. 


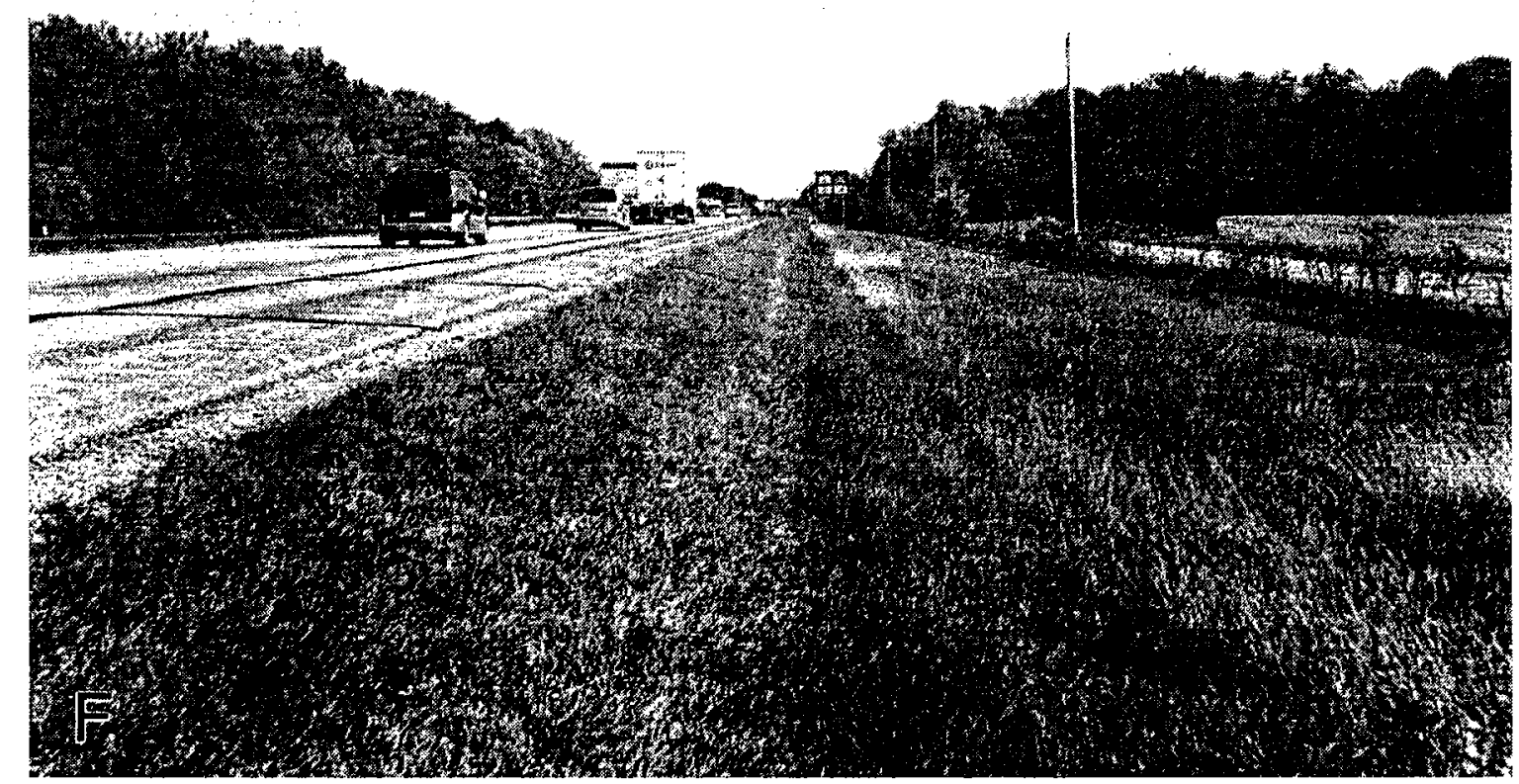

$1 \mathrm{oz} / \mathrm{A}$ Outrider + $0.1 \mathrm{lb} / \mathrm{A}$ GSSG Severe injury to fescue. End of plot clearly demarcated in the background.

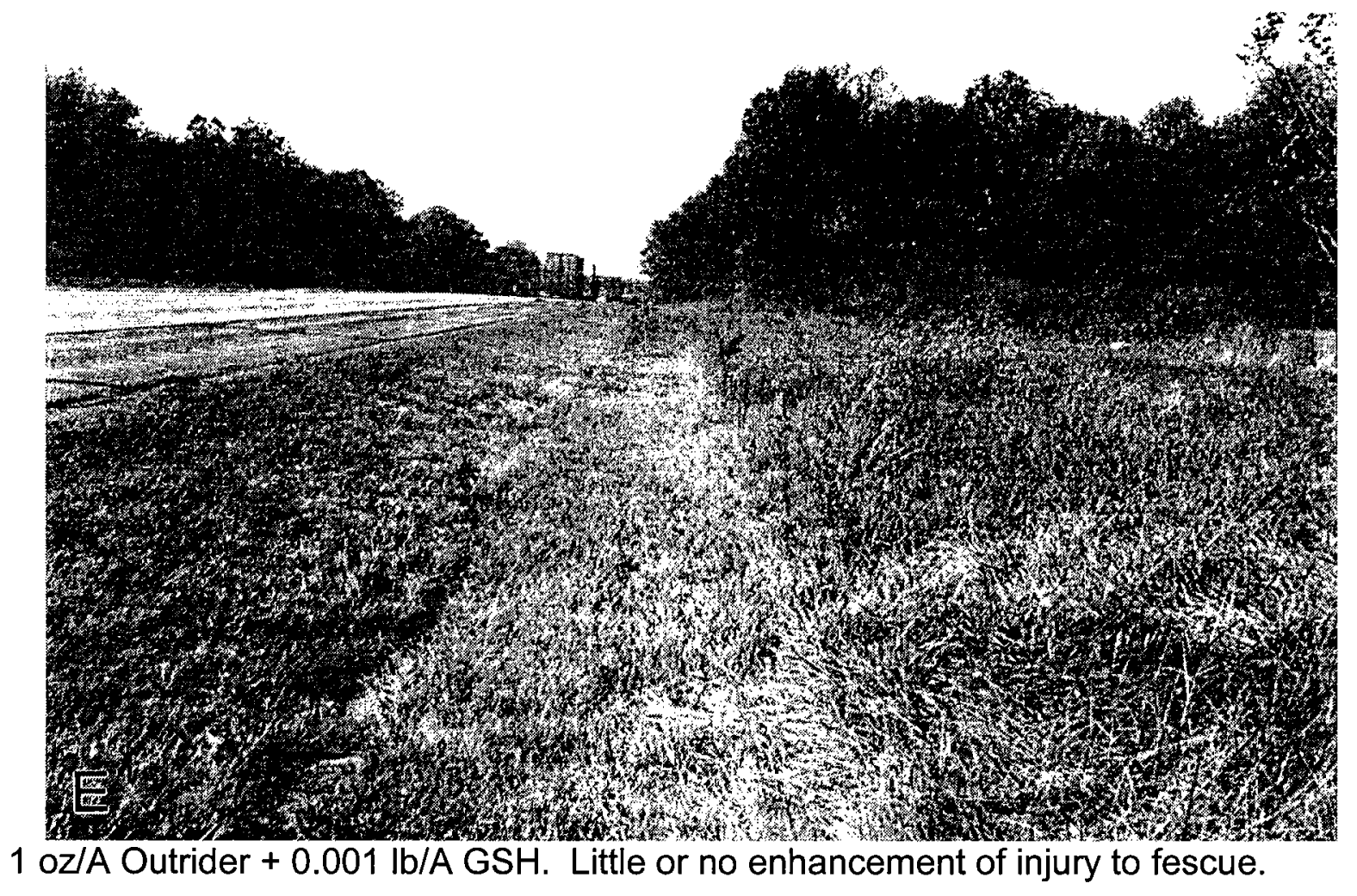




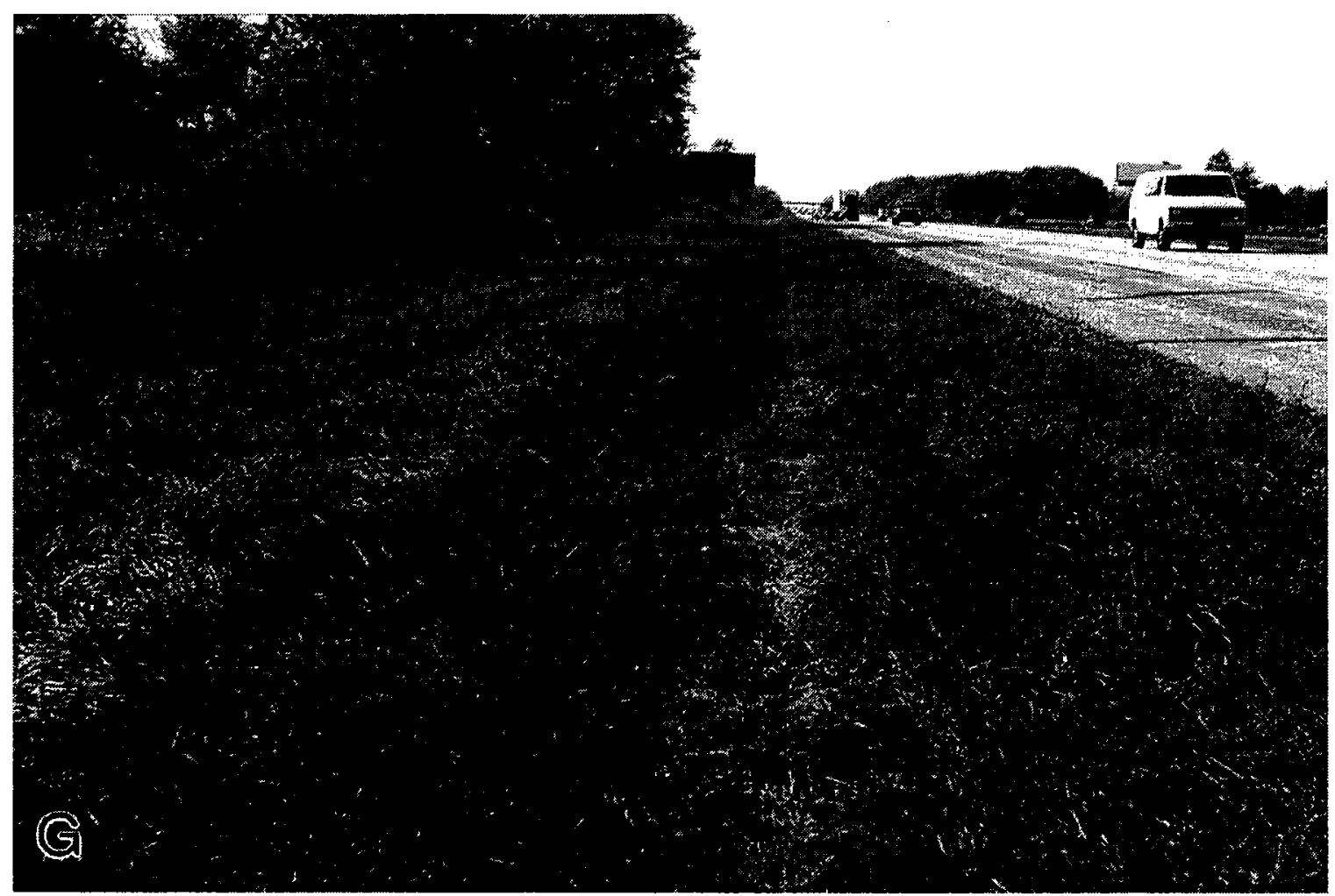

$1 \mathrm{oz} / \mathrm{A}$ Outrider $+0.01 \mathrm{lb} / \mathrm{A}$ GSH. No enhancement of injury to fescue

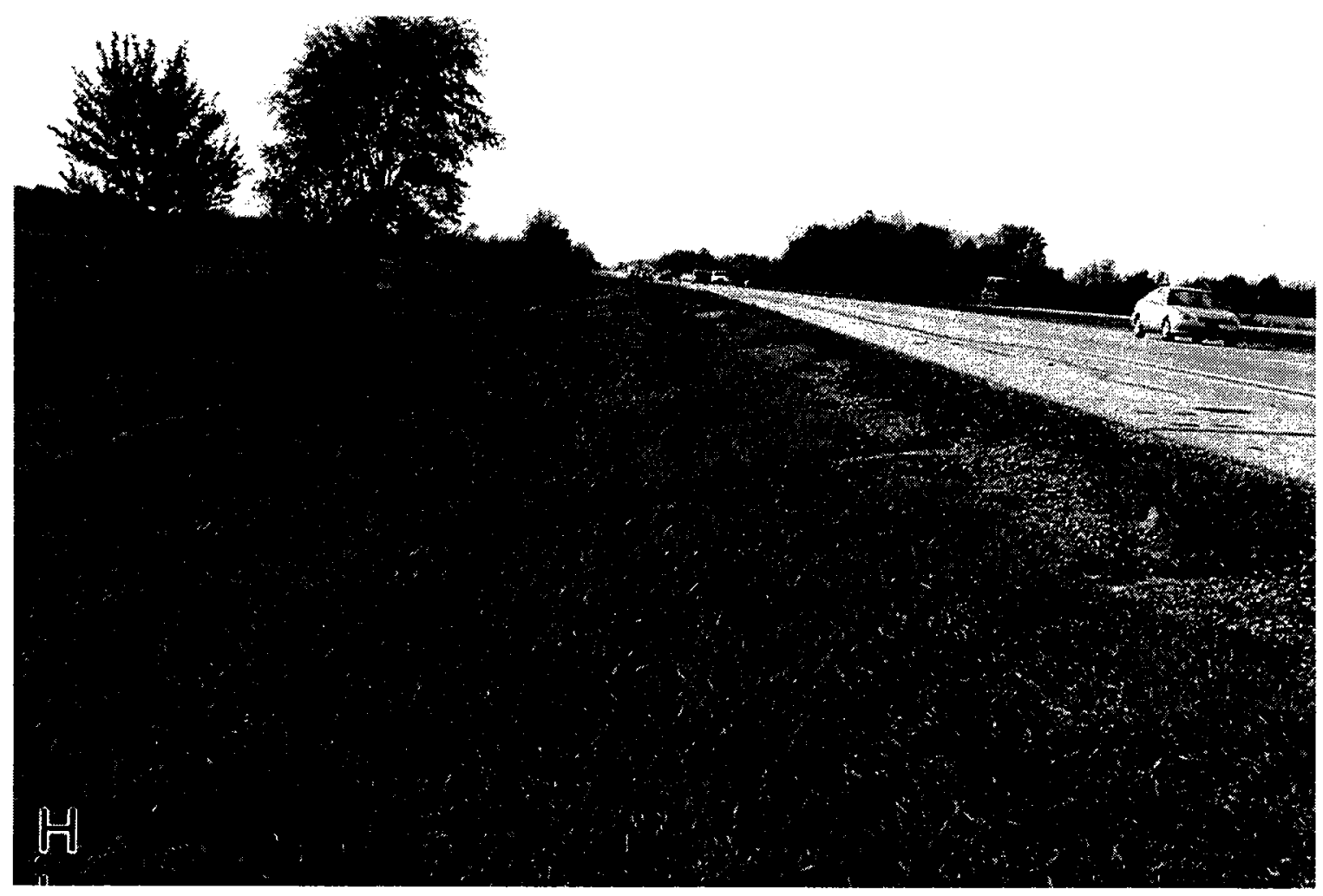

$1 \mathrm{oz} / \mathrm{A}$ Outrider $+0.1 \mathrm{lb} / \mathrm{A}$ GSH. No enhancement of injury to fescue 
even at the highest rate of GSH application in the mixture. 
RESPONSE OF JOHNSONGRASS TO OUTRIDER WITH AND WITHOUT GSSG OR GSH

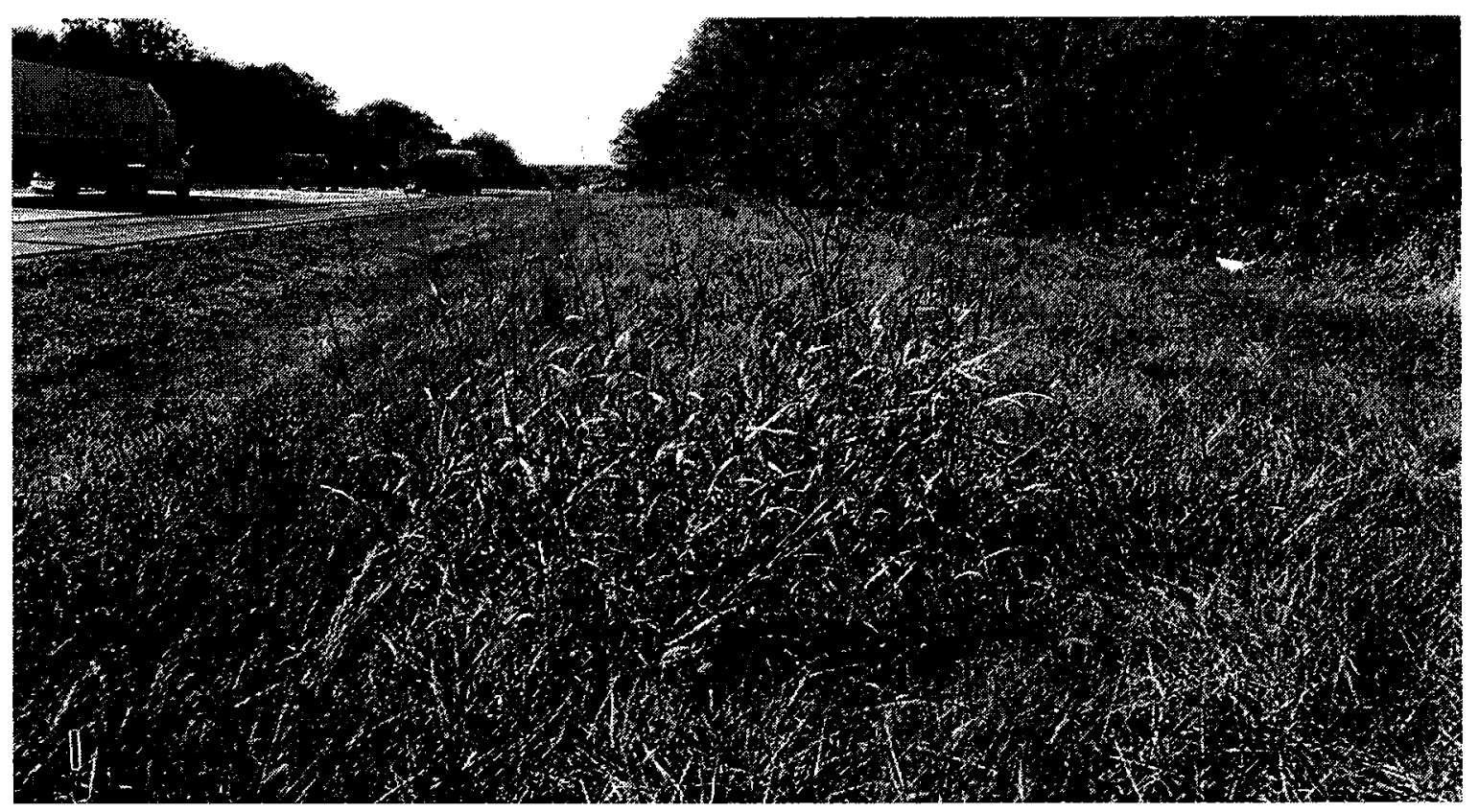

Unsprayed control. The Johnsongrass had frozen but leaves and stems were still green.

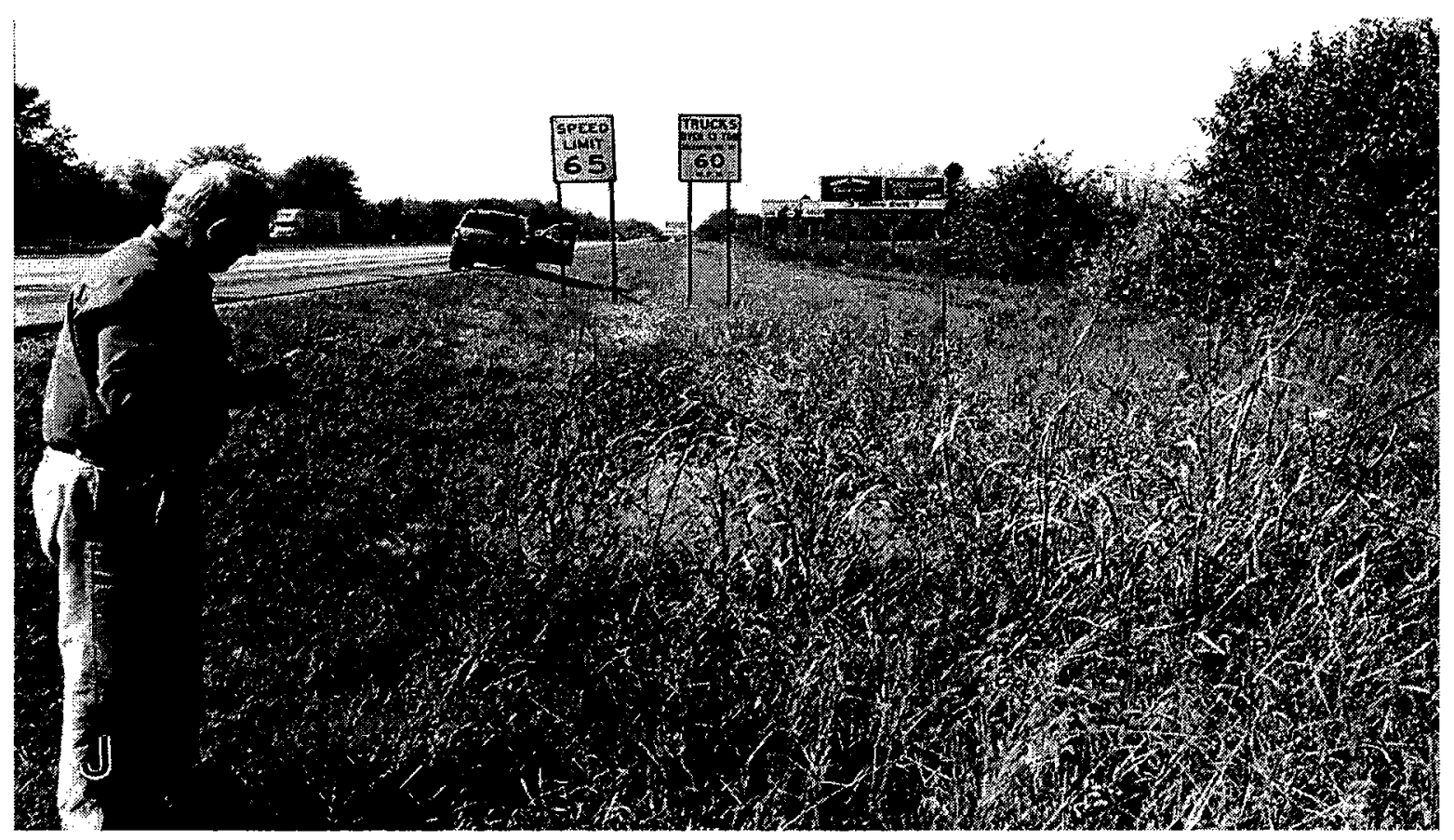

Treatment A. 1 oz/A Outrider 


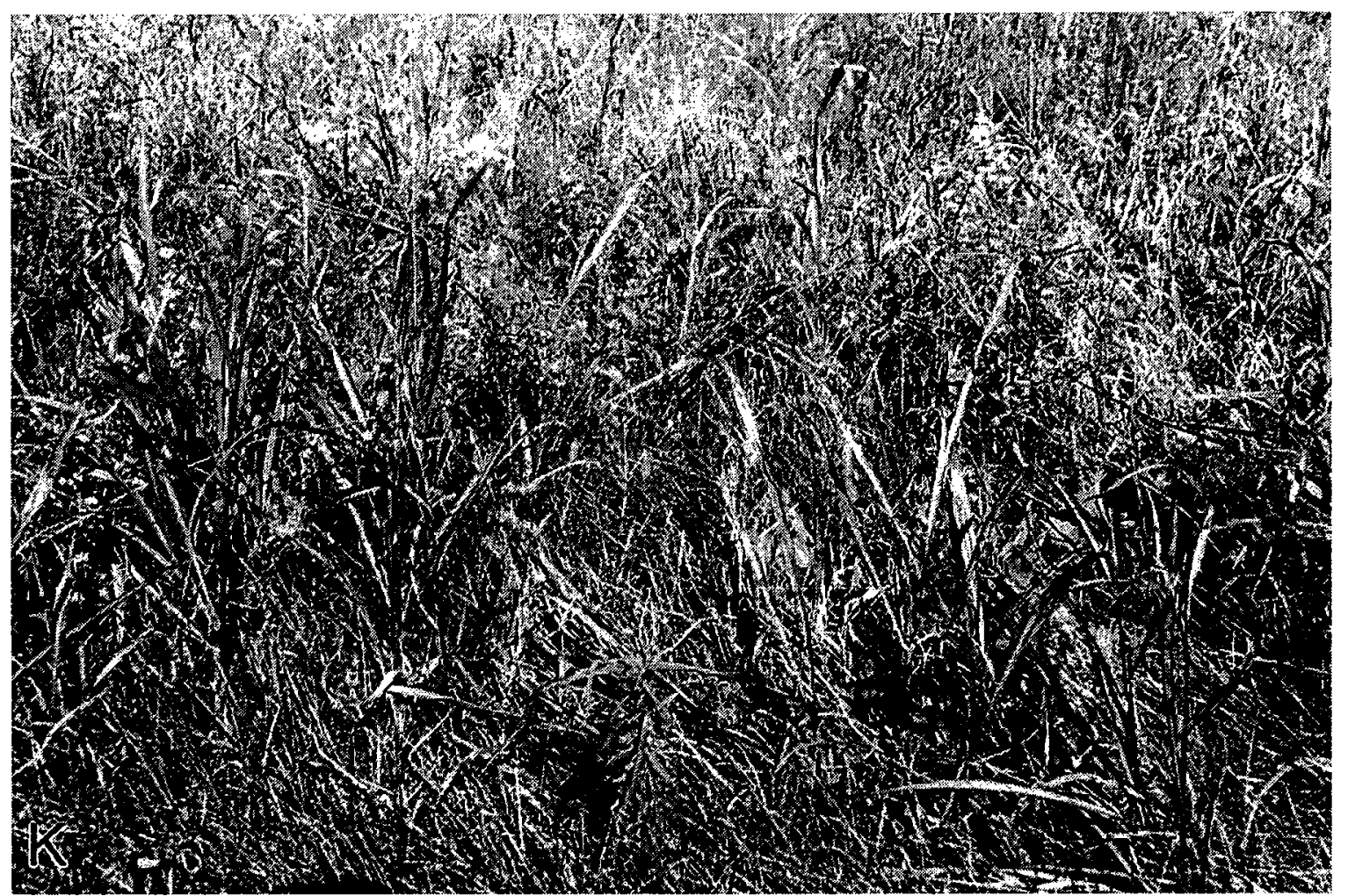

Treatment A. 1 oz/A Outrider. Reddening of leaves. Stems still green.

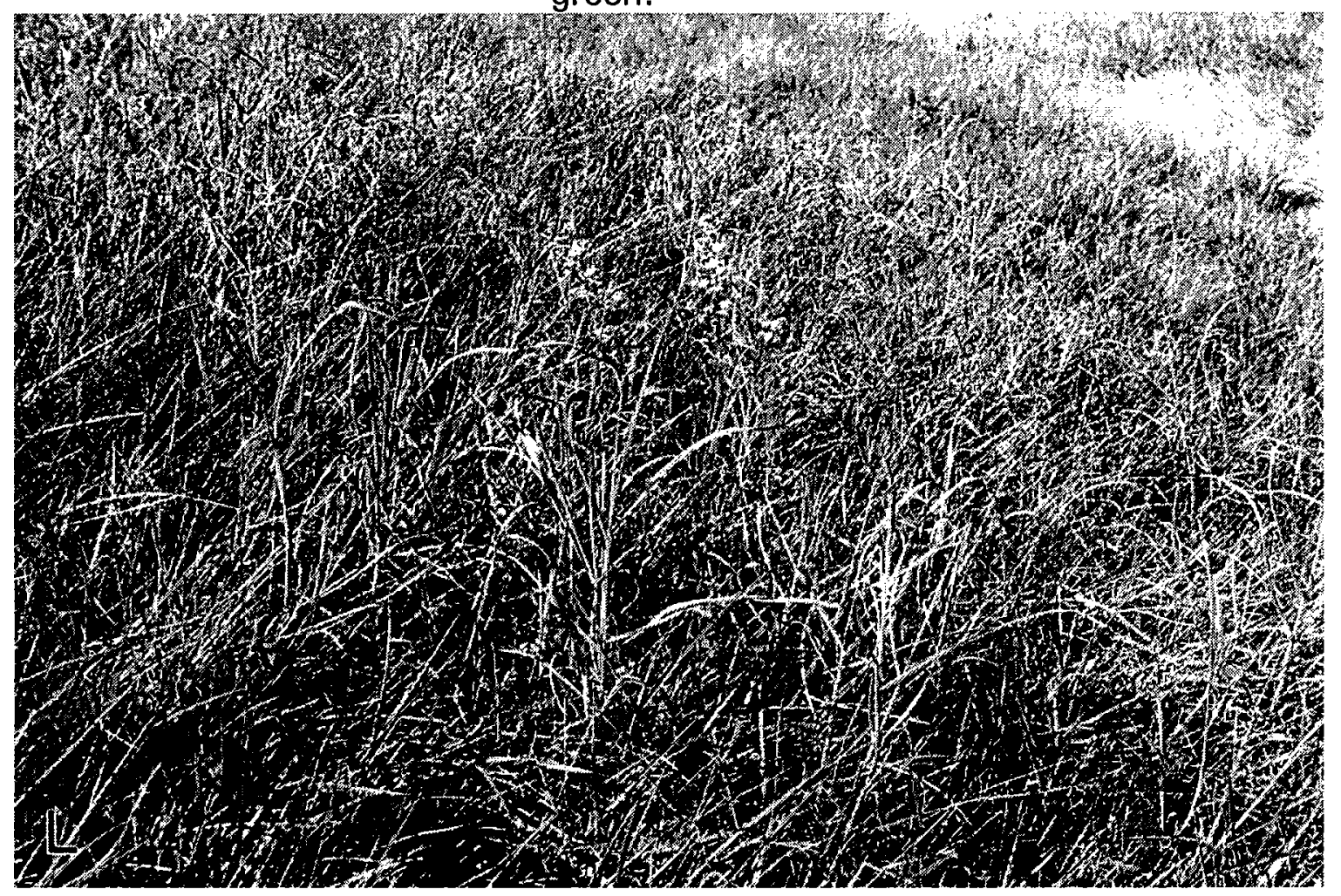

$1 \mathrm{oz} / \mathrm{A}$ Outrider $+0.001 \mathrm{lb} / \mathrm{A}$ GSSG. Stems still green. Perhaps 
less reddening and more browning than Outrider alone. About $30^{\prime \prime}$ high. Few seed heads. 


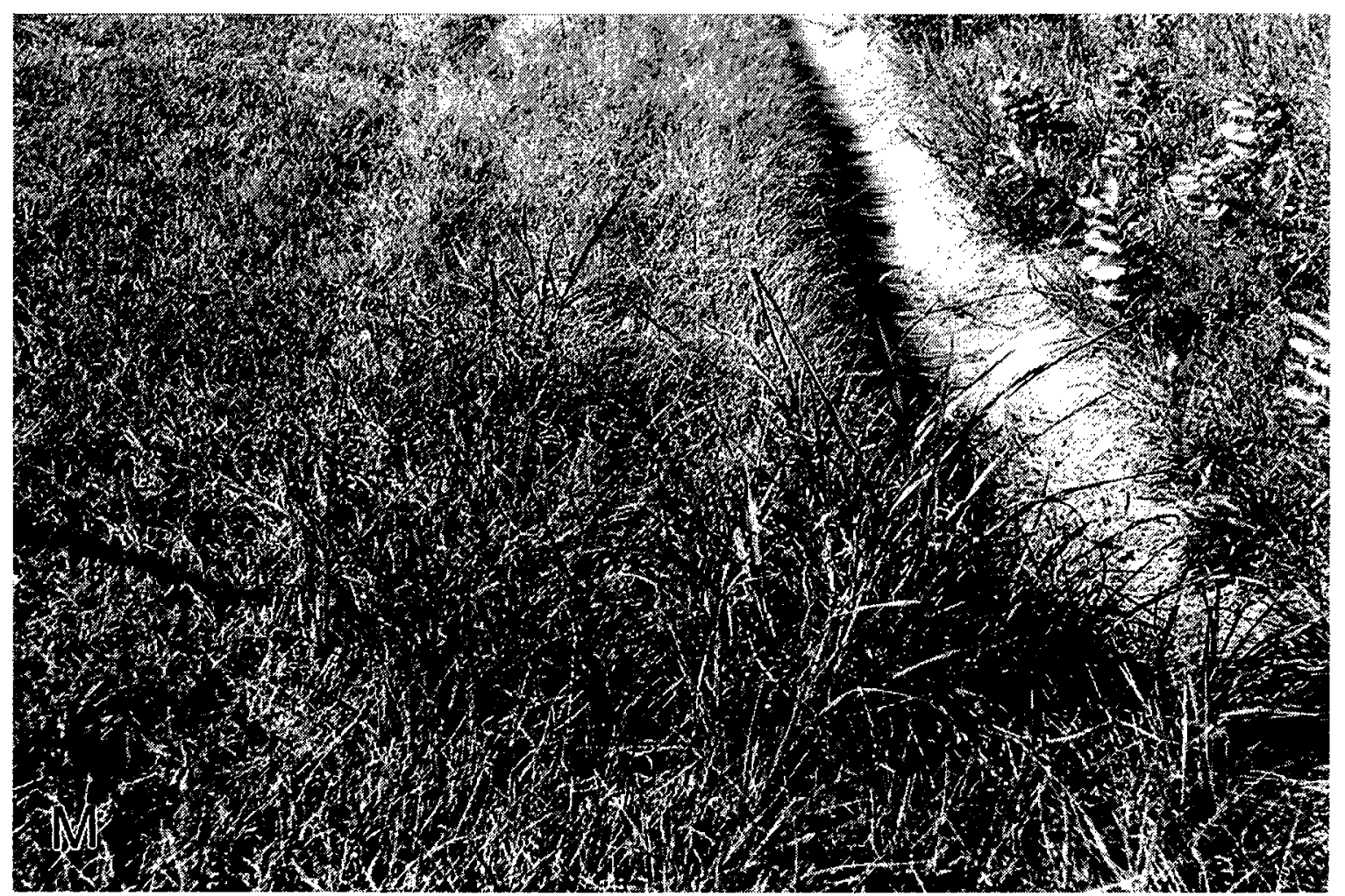

$1 \mathrm{oz} / \mathrm{A}$ Outrider + $0.01 \mathrm{lb} / \mathrm{A}$ GSSG. Uniformly brown. Several culms already dead. 22" high. No seed heads.

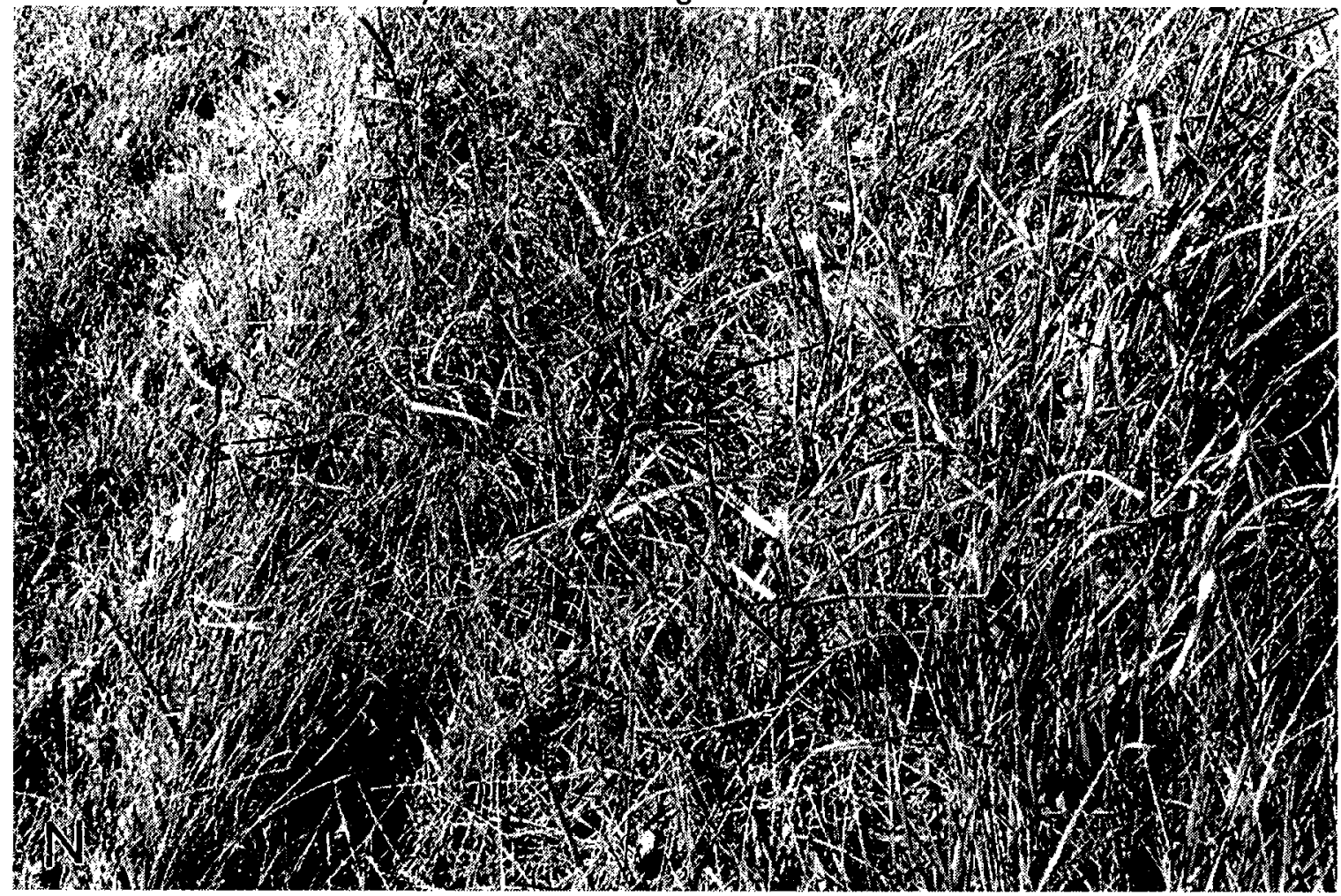

$1 \mathrm{oz} / \mathrm{A}$ Outrider $+0.1 \mathrm{lb} / \mathrm{A}$ GSSG. Left half of clump sprayed. Right half of clump unsprayed. Deep reddening but stems still green. 16" 
high. No seed heads.

PLOTS ON I-70 E BEGINNING MILE MARKER 9 EAST OF US 41 IN TERRE HAUTE

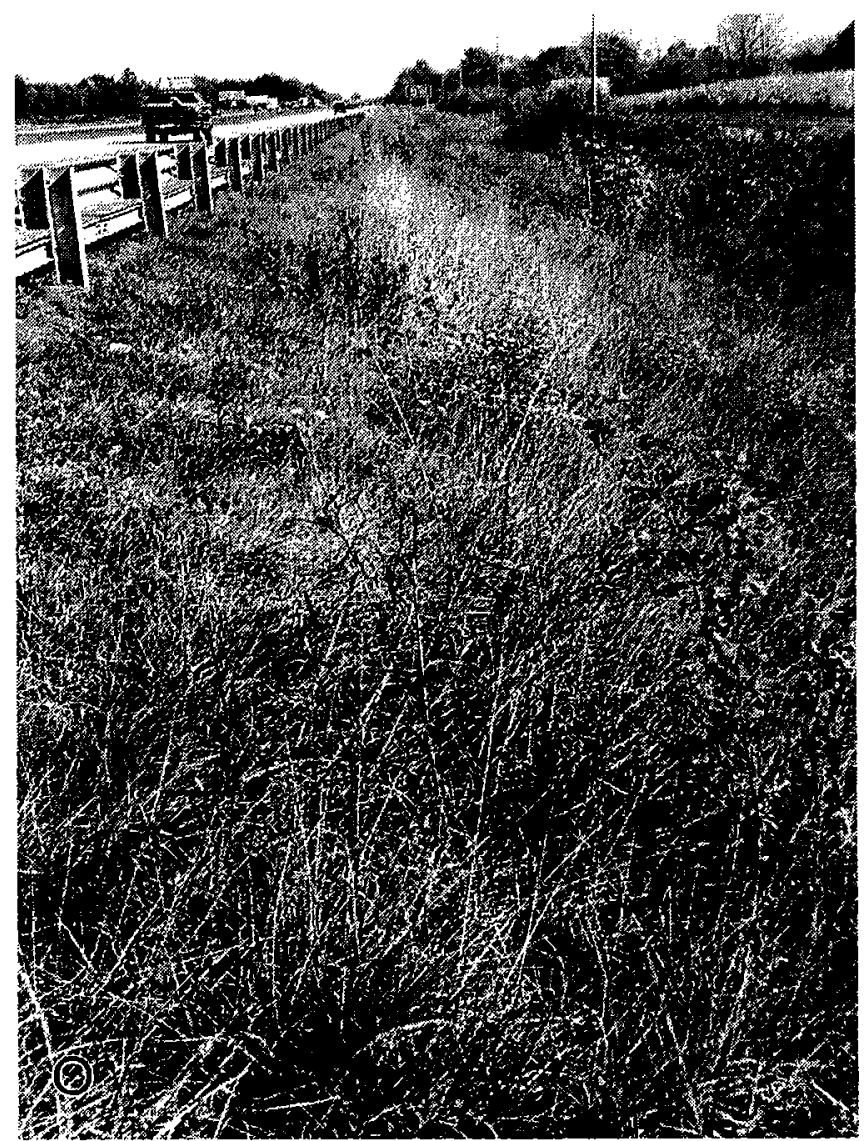

$1 \mathrm{oz} / \mathrm{A}$ Outrider + $0.001 \mathrm{lb} / \mathrm{A}$ GSH. Very effective. Plants brown and many dead.

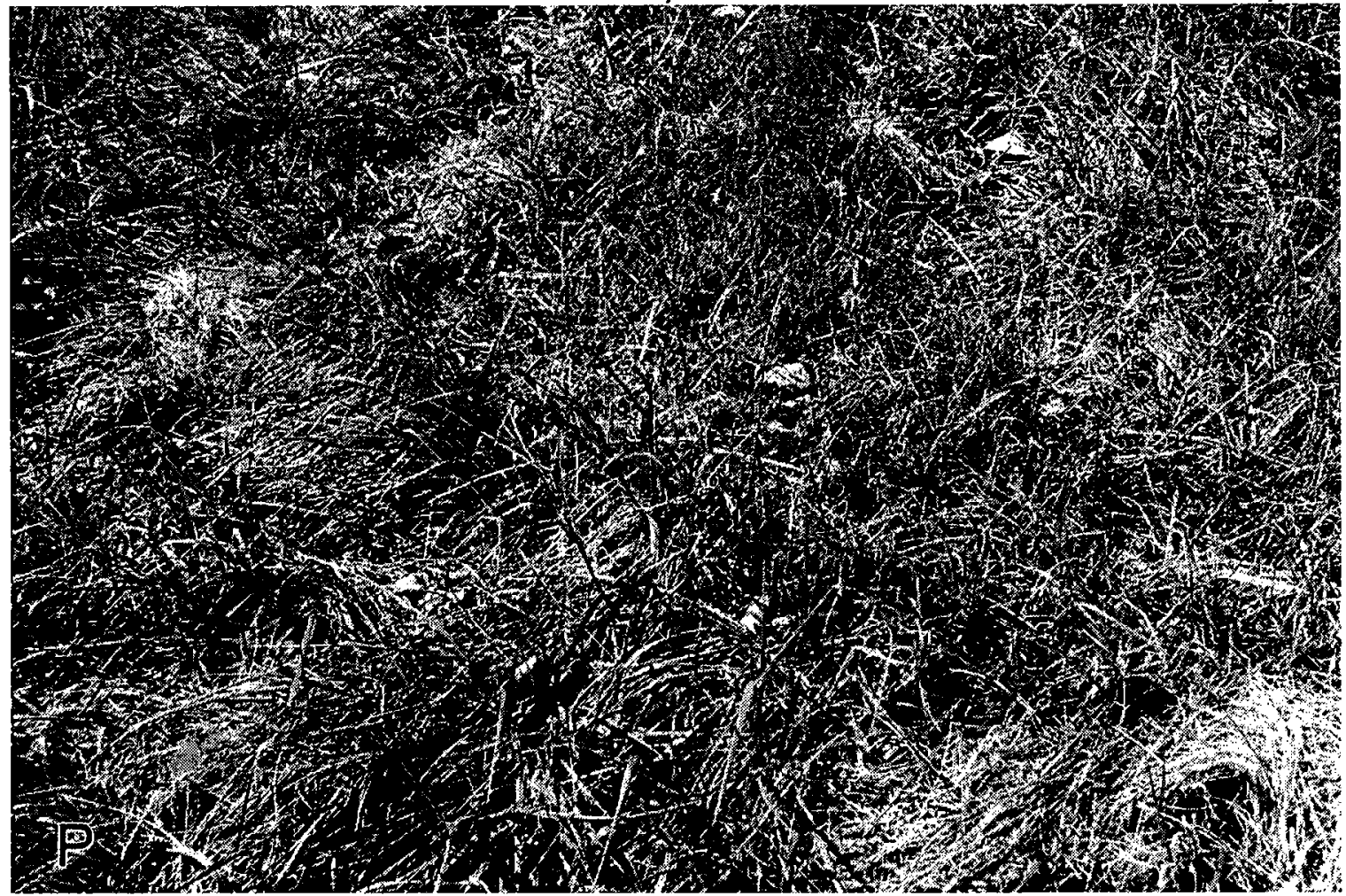


$1 \mathrm{oz} / \mathrm{A}$ Outrider $+0.01 \mathrm{lb} / \mathrm{A} \mathrm{GSH}$. Everything mowed. Unable to evaluate. 


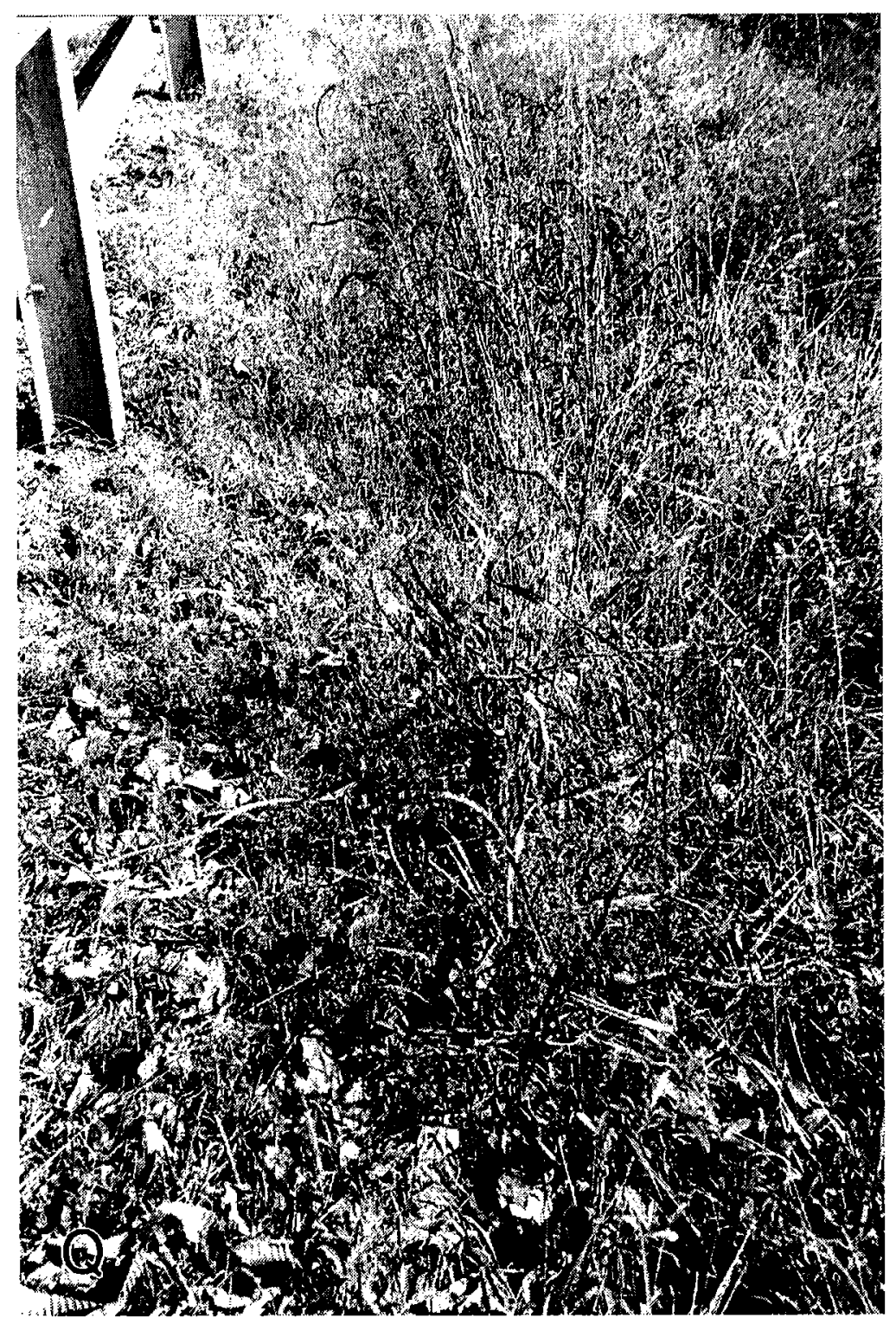

$1 \mathrm{oz} / \mathrm{A}$ Outrider $+0.1 \mathrm{lb} / \mathrm{A}$ GSH. Johnsongrass brown. Appears to be dying. 


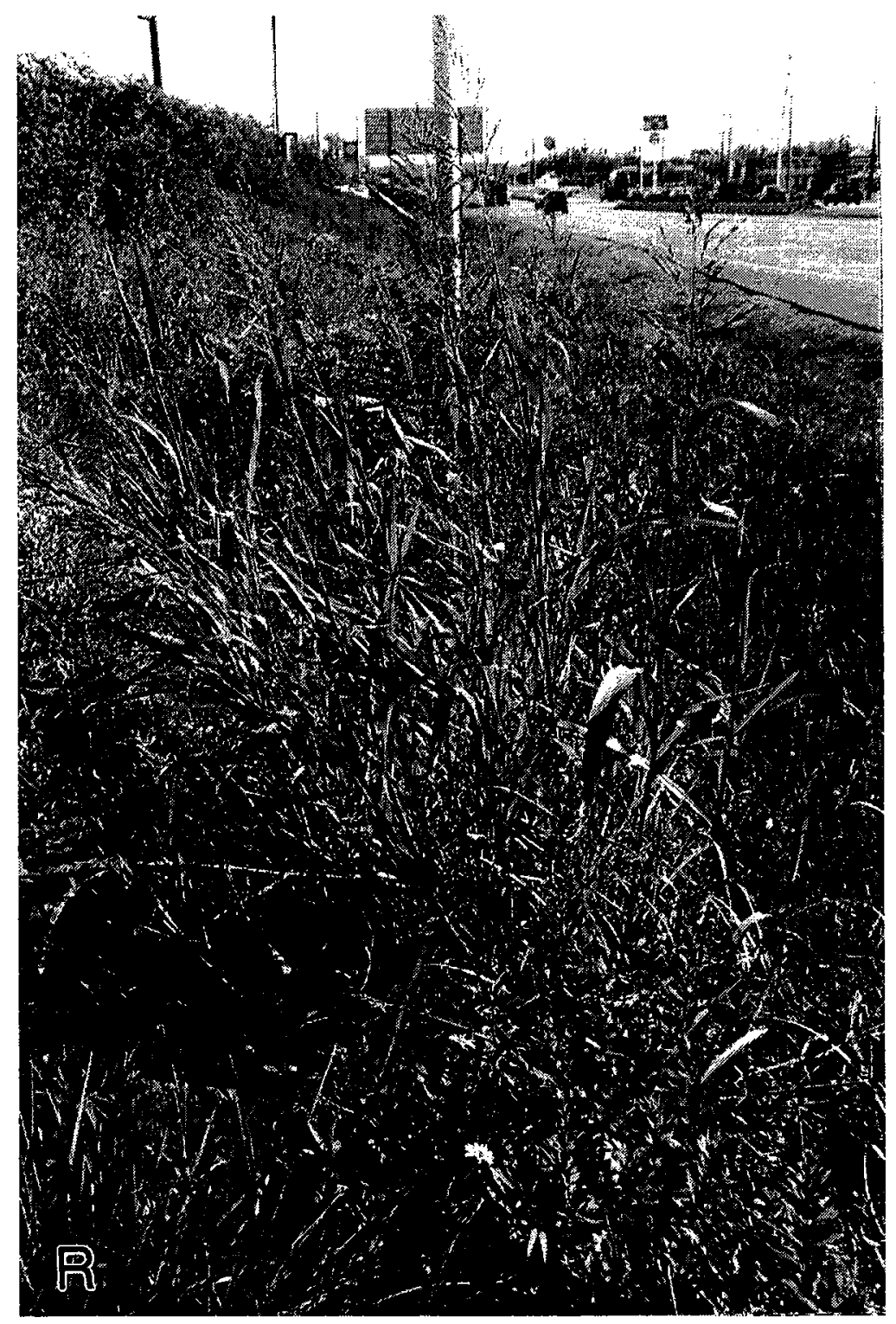

Unsprayed 
A total of three implementation trials were established in the Crawfordsville Dsitrict in 2002 and one additional implementation trail was applied in the Seymour district. All four trials compared Outrider alone and Outrider plus TR-IV and two other additives.

2003

One additional implementation trail was carried out in 2003. The test was on fall regrowth after mowing prior to the last fall mowing cycle. The test was applied on US 63 between junction with US- 36 and Perrysville using Swing Lok Equipment by Dave Sosby of the Crawfordsville District. Two treatments, $1 \mathrm{oz} / \mathrm{A} \mathrm{(70} \mathrm{g/ha)} \mathrm{of} \mathrm{Outrider} \mathrm{alone} \mathrm{and} 1 \mathrm{oz} / \mathrm{A}(70 \mathrm{~g} / \mathrm{ha})$ of Outrider plus $0.01 \mathrm{~kg} / \mathrm{ha}$ additive TR-IV, were compared. Evaluation in October showed the additive to be effective but final evaluation will be based on regrowth in 2004.

Recommended by the SAC Committee in 2004 was the creation of a committed roadside Johnsongrass research area with controlled mowing and date of spraying. The recommended area would be US 63 from Jct. I 74 south to Jct. US 36. This is a moderately low traffic highway, centrally located with abundant Johnsongrass. The roadsides are fenced so that adjacent landowners might be less likely to interfere. State and contractual activities would be carefully regulated and selected no mow and no spray areas would be posted. This is probably imperative if we are to achieve our goals with Johnsongrass control and something that the advisory committee strongly supports.

\section{NORTHWARD MIGRATION OF JOHNSONGRASS. EVOLUTION OF A COLD- HARDY ECOTYPE?}

The northward migration of Johnsongrass was studied in the field, laboratory and greenhouse. The question being posed concerns whether or not this northern Johnsongrass represents the evolution of a new cold-resistant strain of Johnsongrass capable of survival in the Northern United States that would pose a serious new noxious weed threat. Rhizomes from a very large Northern Johnsongrass infestation along SR 4 between North Liberty and South Bend were compared with a large Southern infestation along SR 111 in Indiana north of Louisville. The Johnsongrass rhizomes from the South Bend area and from extreme Southern Indiana were harvested and stored in a $4^{\circ}$ cold room for comparison. The rhizomes were compared for survival at various times and temperatures to try to determine the basis for the apparent northward migration of Johnsongrass in Indiana. The regular collections of rhizomes (November, January, March) revealed that rhizomes did over winter in both locations with no apparent winter kill. Resistance to winter killing was tested by freezing rhizomes at $-12^{\circ} \mathrm{C}$ when collected in January or March. Nearly all rhizomes collected in March from the South Bend location survived freezing at $-12^{\circ} \mathrm{C}$ and produced shoots in the greenhouse whereas only about $50 \%$ of the rhizomes from Southern Indiana survived to produce shoots. The findings suggest that Johnsongrass survival in Northern Indiana is not based on inherent cold hardiness but is somehow related to an enhanced ability to cold harden during the winter and possibly survive in this manner. One meeting was held with Purdue University Agricultural Extension Staff to discuss how the problem of northward migration of Johnsongrass in Indiana might be addressed. Plans are to continue these discussions at some future time. 


\section{BASIC LABORATORY STUDIES}

Basic work has focused on a long term project to clone a key protein of the enzymatic machinery of the plant that responds to the Outrider-TR-IV combination. The work has progressed considerably to the point where an unconfirmed DNA sequence is available.

The interest in sulfonylureas and the target protein goes back before 1986 in regard to mefluidide-chlorsulfuron-2,4-D interactions for retardation of grass growth (chemical mowing, 8-9). These proteins have been studied extensively and intensively for over 10 years (10-14).

The current interest was generated by several observations both plant $(15,16)$ and animal $(17-$ 21) systems that our growth target for the retardants was, indeed, sulfonylurea-sensitive. The redox response came later (22-24). The plant results were patented but largely remain unpublished. With the antitumor sulfonylureas, the redox state (presence of GSH or GSSG) determines therapeutic success or failure. Something similar is anticipated from the Johnsongrass work. In initial laboratory studies, interaction of Outrider with the putative NADH oxidase target was shown in the fall and winter of 2000 and spring of 2001 as exemplified by data of Figure 7A, B for plasma membrane isolated and assayed leaves of both sorghum (Milo) and Johnsongrass. The studies were extended further in fall and winter of 201 and the spring of 2002 as exemplified by data of Figure 8 with leaf pieces of Johnsongrass to show Outrider + GSSG interactions and to set the stage for cloning studies currently underway.

The work progressed considerably in the fall and winter of 2002 and the spring of 2003 to the point where a tentative DNA sequence is now available. The correctness of the protein, in any event, will require extensive confirmation before we can be certain of success. The protein was isolated and a monoclonal antibody to the protein was generated. The monoclonal antibody was used to expression clone the putative Outrider-TR-IV target DNA. The expressed protein was to have been used to evaluate Outrider and TR-IV ratios as well as to speed the discovery of related alternative to the TR-IV additive. 


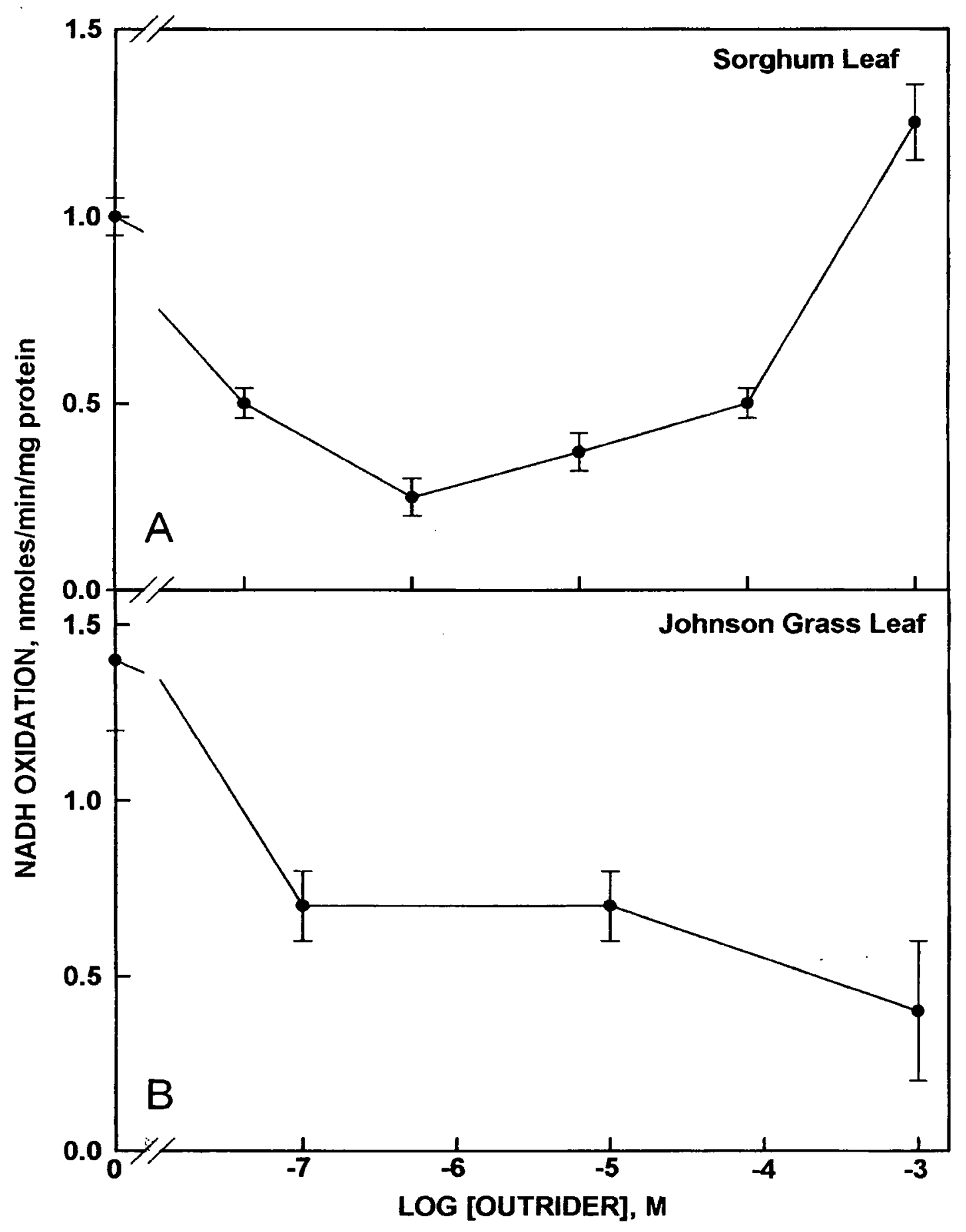

Figure 7. Laboratory assays of NADH oxidase activity with plasma membranes isolated from sorghum (A) or Johnsongrass (B) leaves to show the response of the putative Outrider target NADH oxidase to Outrider. 


\section{Johnson Grass Leaves}

08/06/04

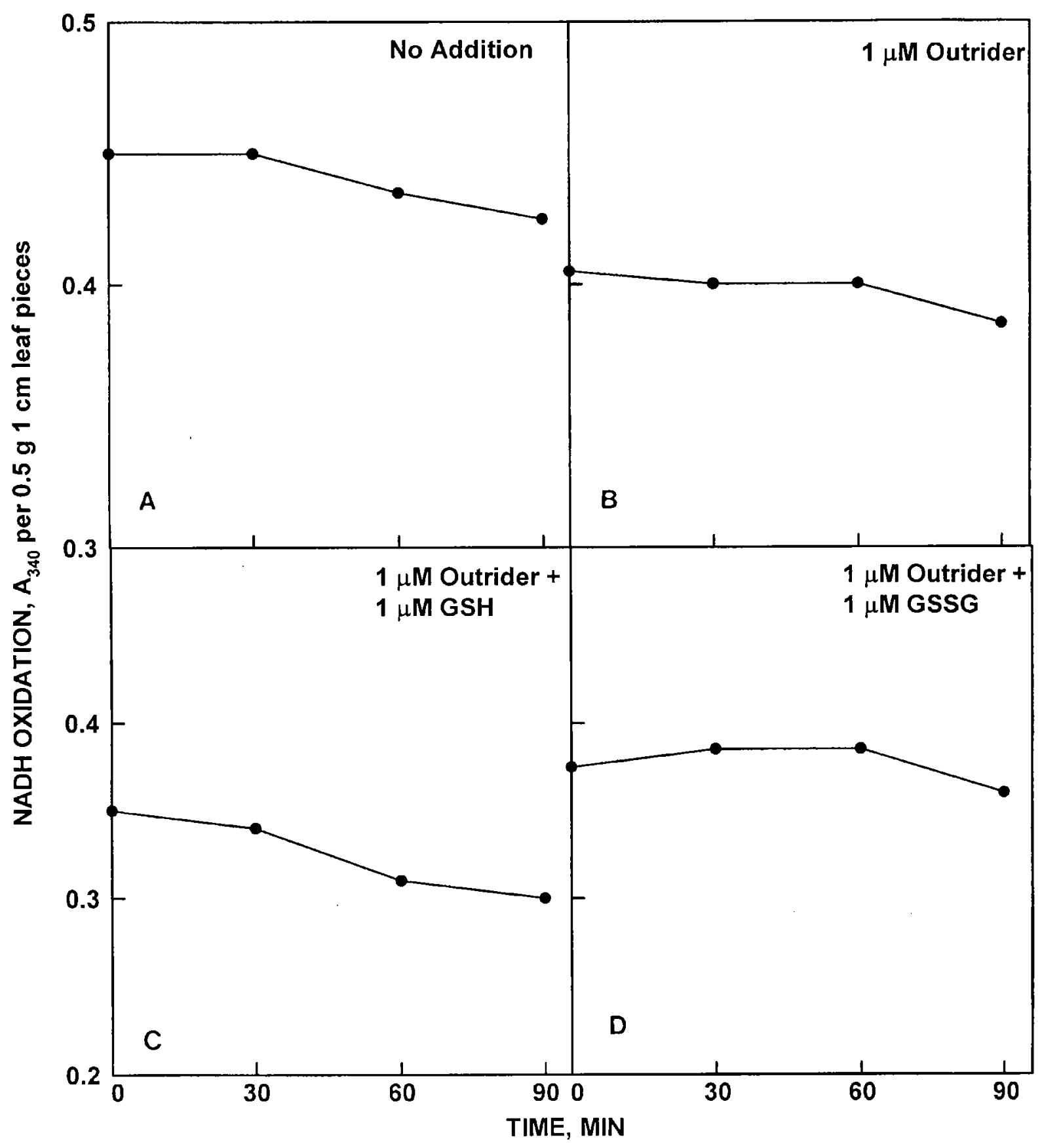

Figure 8. Laboratory assays of NADH oxidase activity with $1 \mathrm{~cm}$ leaf pieces of Johnsongrass (A) to show interaction with Outrider (B) and Outrider plus GSSG (D) or Outrider plus GSH (C). 
Field trials in 2003 focused on evaluations of various salt additives identified from laboratory studies as possible enhancers of Outrider for control of Johnsongrass. Evaluated were ammonium sulfate, urea and ammonium nitrate. Ammonium nitrate and urea were used previously as brush control additives with optimum response at $1 \mathrm{lb} / \mathrm{A}(1 \mathrm{~kg} / \mathrm{ha})$. When tested in combination with Outrider and GSSG, none of the mixtures with salts were more effective than Outrider alone (Table 9).

Also tested in 2003 were rate and date studies to determine the amount of Outrider + GSSG required to eradicate Johnsongrass in July and August alone and in combination with urea or ammounium sulfate. In five of seven trials, the plots were oversprayed with Roundup 2 to 6 weeks following treatment as the Johnsongrass began to redden as a result of the Outrider. In these trials, Johnsongrass was completely eradicated by the double treatment even at the lowest rate of $0.5 \mathrm{oz} / \mathrm{A}$ Outrider in the absence of any other additive (Table 10). Roundup by itself gave only $25 \%$ control on average in these trials and Outrider alone at $0.5 \mathrm{oz} / \mathrm{A}$ gave only $56 \%$ eradication. Sequential applications of Outrider followed by Roundup might be more economical in the long run than Outrider plus GSSG additive as a single application.

Material costs for Outrider at $1 \mathrm{oz} / \mathrm{A}$ would be $\$ 210$ plus ca $\$ 100$ for $0.01 \mathrm{lb} / \mathrm{A}$ GSSG additive or a total materials cost of $\$ 310$.

Assuming a reduction of Outrider to $0.5 \mathrm{oz} / \mathrm{A}$ or less and a Roundup application of no more that $1.0 \mathrm{lb} / \mathrm{A}$, material costs would be reduced by more than $70 \%$ to less than $\$ 100$ per acre.

Another advantage of the sequential Outrider followed by Roundup strategy is that timing is apparently not critical nor is stage of growth limiting. Apparently quite mature Johnsongrass already forming seed heads can be controlled by the treatment. 
Table 9. Effect of several salt additives on Johnsongrass eradication. Applications were between June 27 and August 30, 2003 averaged from 12 different locations. All treatments contained Outrider, $1 \mathrm{oz} / \mathrm{A}, \mathrm{GSSG}, 0.001 \mathrm{lb} / \mathrm{A}$ and the salt additive at $1 \mathrm{lb} / \mathrm{A}$. Evaluations were in August 2004. See page 29 for metric equivalents.

Treatment + salt additive

$\%$ Control [(Ratio of final stand count to initial stand count X 100) - 100]

None (check)

Outrider alone + none

72

Outrider + GSSG + none

85

Outrider + GSSG + ammonium sulfate

67

Outrider + GSSG + urea

71

Outrider + GSSG + ammonium nitrate

70

*Check plots contained 5\% more plants in 2004 than in 2003.

Table 10. Effect of subsequent applications of Roundup (glyphosate) on eradication of Johnsongrass treated with varying rates of a mixture of Outrider, GSSG and urea or ammonium sulfate. See page 29 for metric equivalents.

Primary treatment*

$\%$ Control after Roundup

None 25

Outrider $0.5 \mathrm{oz} / \mathrm{A}$

100

Outrider 1 oz/A

100

Outrider $1.5 \mathrm{oz} / \mathrm{A}$

100

Outrider $1 \mathrm{oz} / \mathrm{A}$

100

Outrider $0.5 \mathrm{oz} / \mathrm{A}+\mathrm{GSSG} 0.005 \mathrm{lb} / \mathrm{A}$

95

Outrider $1 \mathrm{oz} / \mathrm{A}+\mathrm{GSSG} 0.01 \mathrm{lb} / \mathrm{A}$

100

Outrider $1.5 \mathrm{oz} / \mathrm{A}+\mathrm{GSSG} 0.015 \mathrm{lb} / \mathrm{A}$

100

Outrider $2 \mathrm{oz} / \mathrm{A}+\mathrm{GSSG} 0.02 \mathrm{lb} / \mathrm{A}$

100

Outrider $0.5 \mathrm{oz} / \mathrm{A}+\mathrm{GGSG} 0.005 \mathrm{lb} / \mathrm{A}+$ urea $0.5 \mathrm{lb} / \mathrm{A}$

100

Outrider $1 \mathrm{oz} / \mathrm{A}+$ GGSG $0.01 \mathrm{lb} / \mathrm{A}+$ urea $1 \mathrm{lb} / \mathrm{A}$

100

Outrider $1.5 \mathrm{oz} / \mathrm{A}+\mathrm{GSSG} 0.015 \mathrm{lb} / \mathrm{A}+$ urea $1.5 \mathrm{lb} / \mathrm{A}$

100

Outrider $2 \mathrm{oz} / \mathrm{A}+\mathrm{GSSG} 0.02 \mathrm{lb} / \mathrm{A}+$ urea $2 \mathrm{lb} / \mathrm{A}$ 100

*Applied July 4, July 27, August 7 and August 22, 2003.

**Applied ca 2 to 6 weeks after treatment with Outrider + GSSG + urea or ammonium sulfate after the Johnsongrass began to redden as a result of the Outrider treatment. 


\section{LIST OF REFERENCES}

1. W. L. Barrentine, and C. G. McWhorter, "Johnsongrass (Sorghum halepense) control with herbicides in oil diluents," Weed Science, Vol. 36, 1988, pp. 102-110.

2. R. L. Brooks, M. G. Merkle, and J. M. Chandler, "Efficacy of glyphosate/adjuvant combinations for Johnsongrass control," Proc. South. Weed Sci. Scoc., 38, 1985, pp. 46.

3. C. M. Ghersa, E. H. Satorre, and M. L. Van Esso, "Seasonal patterns of Johnsongrass seed production in different agricultural systems," Israel J. Bot., 34, 1985, pp. 24-31.

4. E. S. Leguizamon, "Seed survival and patterns of seedling emergence in Sorghum halepense (L.) Pers.," Weed Res., 20, 19986, pp. 397-404.

5. C. G. McWhorter, "Factors affecting Johnsongrass rhizome production and germination," Weed Sci., 20, 1972, pp. 41-45.

6. C. G. McWhorter, "History, biology, and control of Johnsongrass," Res. Weed Sci., 4, 1972, pp. 85-121.

7. E. H. Satorre, C. M. Ghersa, and A. M. Pataro, "Prediction of Sorghum halepense (L.) Pers. rhizome sprout emergence in relation to air temperature," Weed Res., 25, 1985, pp. 103109.

8. D. J. Morré, "New program of chemical mowing along Indiana roadsides," TRB Transportation Research Record, 913, 1983, pp. 16-18.

9. D. J. Morré and K. Tautvydas, "Mefluidide-chlorsulfuron-2,4-D-surfactant combinations for roadside vegetation management," J. Plant Growth Regulation 4, 1986, pp. 189-201.

10. D. J. Morré, P. Navas, C. Penel and F. J. Castillo, "Auxin-stimulated NADH oxidase (semidehydroascorbate reductase) of soybean plasma membrane: Role in acidification of cytoplasm"," Protoplasma 133, 1986, pp. 195-197.

11. A. O. Brightman, R. Barr, F. L. Crane and D. J. Morré, "Auxin- stimulated NADH oxidase purified from plasma membrane of soybean," Plant Physiol. 86. 1099. pp. 1264-1269.

12. D. J. Morré, A. O. Brightman, A. Hidalgo and P. Navas, "Selective inhibition of auxinstimulated NADH oxidase activity and elongation growth of soybean hypocotyls by thiol reagents," Plant Phys. 107, 1995, pp. 1285-1291.

13. D. J. Morré and D. M. Morré, "Differential response of the NADH oxidase of plasma membranes of rat liver and hepatoma and HeLa cells to thiol reagents," J. Bioenerg. Biomemb. 27, 1995, pp. 137-144.

14. D. J. Morré, "The role of NADH oxidase in growth and physical membrane displacement," Protoplasma 184, 1995, pp. 14-21. 
15. D. J. Morré, Morré, D. J., R. de Cabo, E. Jacobs and D. M. Morré, “Auxin-modulated protein disulfide-thiol interchange activity from soybean plasma membranes," Plant Physiol. 109, 1995, pp. 573-578.

16. D. J. Morré, J. Fleurimont and M. Sweeting, "Chlorsulfuron blocks 2,4-D-induced cell enlargement and NADH oxidase in excised sections of soybean hypocotyls," Biochim. Biophys Acta 1240, 1995, pp. 5-9.

17. D. J. Morré, D. M. Morré, J. Stevenson, W. MacKellar and D. McClure, "HeLa plasma membranes bind the antitumor sulfonylurea LY181984 with high affinity," Biochim. Biophys. Acta 1244, 1995, pp. 133-140.

18. S. Y. Moya-Camarena, D. J. Morré and D. M. Morré, "Response of NADH oxidation and growth in K-562 cells to the antitumor sulfonylurea, N-(4-methylphenylsulfonyl)-N(-(4chlorophenyl)urea (LY181984)," Protoplasma 188, 1995, pp. 151-160.

19. D. J. Morré, L.-Y. Wu and D. M. Morré, "The antitumor sulfonylurea N-(4methylphenylsulfonyl)-N(-(chlorophenyl)urea (LY181984) inhibits NADH oxidase activity of HeLa plasma membranes," Biochim. Biophys. Acta 1240, 1995, pp. 11-17.

20. D. J. Morré, 'NADH oxidase activity of HeLa plasma membranes inhibited by the antitumor sulfonylurea N-(4-methylphenylsulfonyl)-N-(4-chlorophenyl)urea (LY181984) at an external site," Biochim. Biophys. Acta 124,1995, pp. 201-208.

21. D. J. Morré, E. Jacobs, M. Sweeting, R. de Cabo and D. M. Morré, "A protein disulfide-thiol interchange activity of HeLa plasma membranes inhibited by the antitumor sulfonylurea $\mathrm{N}$ (4-methylphenylsulfonyl)- $N$ '-(4-chlorophenyl)urea (LY181984)." Biochim. Biophys. Acta 1325,1997 , pp. 117-125.

22. D. J. Morré, L.-Y. Wu and D. M. Morré, " Inhibition of NADH oxidase activity and growth of $\mathrm{HeLa}$ cells by the antitumor sulfonylurea, $N$-(4- methylphenylsulfonyl)- $N^{\prime}$-(4chlorophenyl)urea and response to epidermal growth factor," Biochim.Biophys. Acta 1355, 1997, pp. 114-120.

23. D. J. Morré, L.-Y. Wu and D. M. Morré, " Response of a cell-surface NADH oxidase to the antitumor sulfonylurea $N$-(chlorophyenylsulfonyl)- $N$ '-(4-chlorophenyl)urea (LY181984) modulated by redox," Biochim. Biophys. Acta 1369, 1998, pp. 185-192.

24. D. J. Morré, J. C. Rodriguez-Aguilera, P. Navas and D. M. Morré, "Redox modulation of the response of NADH oxidase activity of rat liver plasma membranes to cyclic AMP plus ATP," Mol. Cell. Biochem. 173, 1997, pp. 71-77. 


\section{CONCLUSIONS}

This project was to develop a cost-effective method for chemical eradication of Johnsongrass along Indiana roadsides. Johnsongrass, together with Canada thistle, represents Indiana's most serious noxious weed invader where the need for control is mandated by law. Combined targetdirected laboratory and greenhouse studies identified a new candidate herbicide, Outrider which when combined with a new additive designated TR-IV gives eradication of Johnsongrass when applied to plants after less than 20 inches $(70 \mathrm{~cm})$ of growth or regrowth $\mathbb{I N}$ July or August following mowing. The combination does not harm oversprayed established fescue or bluegrass. Based on limited implementation activities (two years experience), the recommendation is as a spot treatment.

A cold-adapted Johnsongrass ecotype has been identified in the Northern-most tier of counties in Indiana which provides a further threat of encroachment of roadside-established Johnsongrass onto adjacent cropland of considerable potential economic consequence.

\section{RECOMMENDATIONS}

1. Use of a combination of $1 \mathrm{oz} / \mathrm{A}$ (70 g/ha) Outrider plus $0.01 \mathrm{~kg} / \mathrm{ha}$ of additive TR-IV (GSSG) as a spot treatment to eradicate Johnsongrass.

2. Best applied to regrowth less than 20 inches $(70 \mathrm{~cm})$ high in July or August.

3. Mowing approximately 1 month following the application may be beneficial.

\section{IMPLEMENTATION SUGGESTIONS}

It is suggested that the recommendation of the SAC Committee to create a committed roadside Johnsongrass research area with controlled mowing and date of spraying be followed as a means of further implementation. The recommended area was US-63 from Jct. I-74 south to Jct. US36. A moderately low traffic highway and centrally located where Johnsongrass is abundant. The roadsides are fenced so that adjacent landowners are less likely to interfere. State and contractual activities would be carefully regulated and selected no mow and no spray areas would be posted. This is probably imperative if we are to achieve the goal of chemical control eradication of Johnsongrass along Indiana roadsides. 